NASA TECHNICAL NOTE

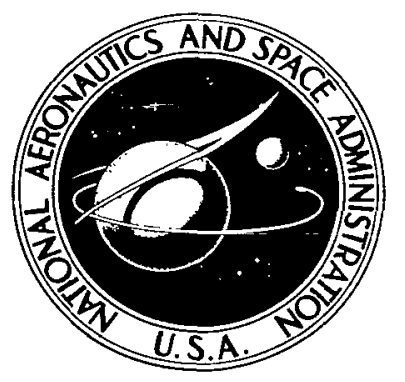

NASA TN D-8493

c.

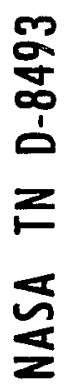

LOAN COPY: RETI AFWL TECHNICAL I KIRTLAND AFB,

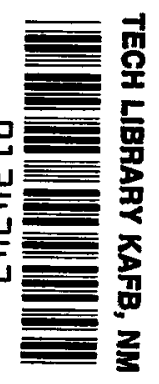

EFFECT OF SIMULATED EARTH REENTRY EXPOSURE ON MECHANICAL

PROPERTIES OF SEVERAL OXIDE DISPERSION STRENGTHENED AND

SUPERALLOY SHEET MATERIALS

J. Daniel Whittenberger

Lewis Research Center

Cleveland, Obio 44135

NATIONAL AERONAUtics AND SPACE adMINISTRATION - WASHINGTON, D. C. MAY 1977 


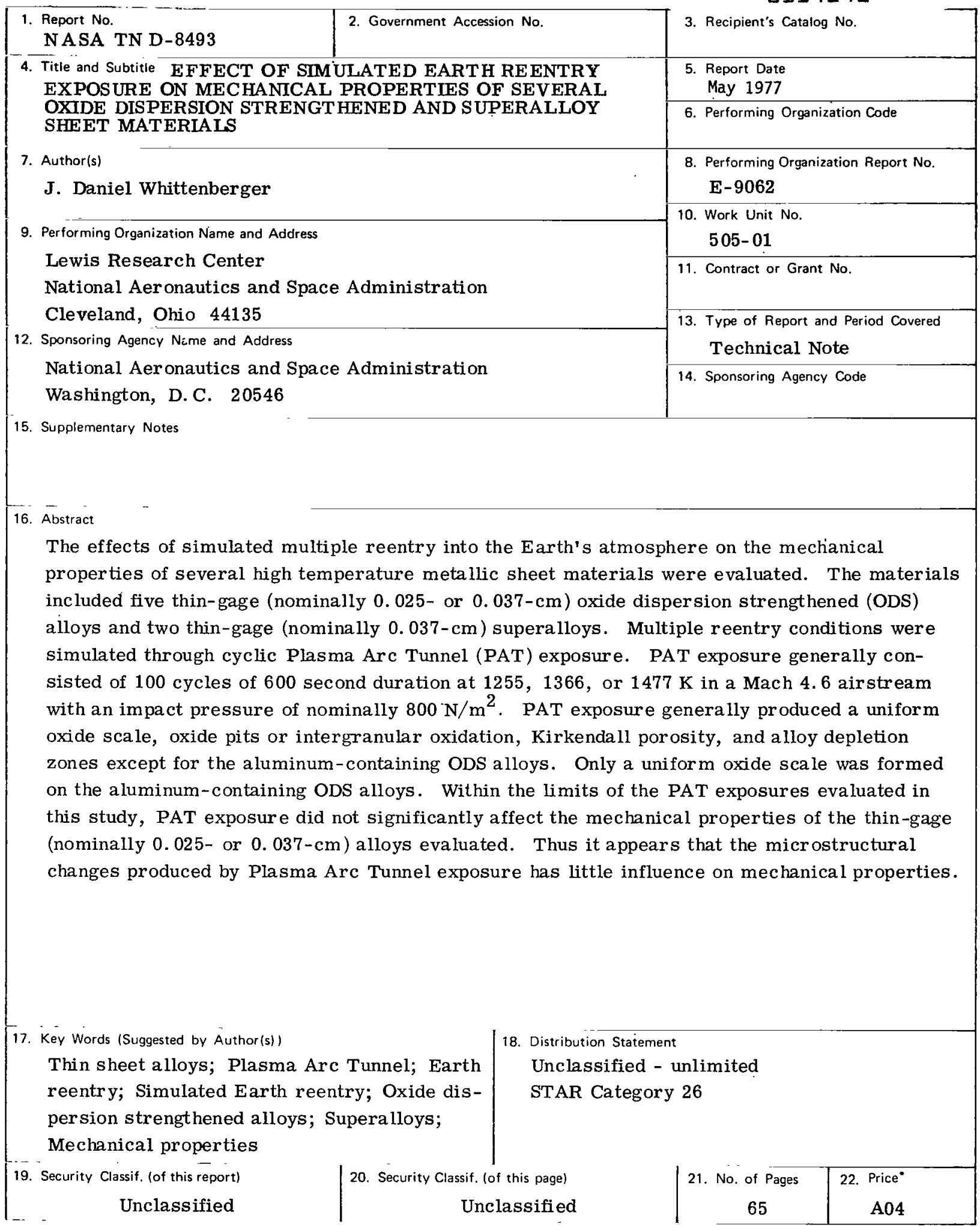

* For sale by the National Technical Information Service, Springfield, Virginia 22161 



\section{CONTENTS}

Page

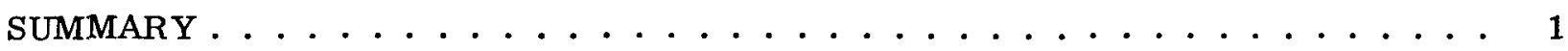

INTRODUCTION .............................. 2

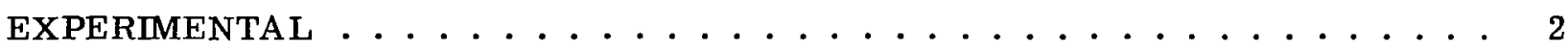

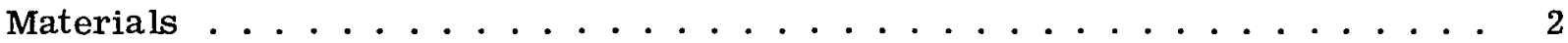

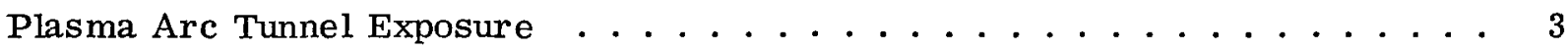

Postexposure Evaluation ...................... . . . 4

RESULTS AND DISCUSSION . . . . . . . . . . . . . . . . . . 5

Structural Effects of PAT Exposure . . . . . . . . . . . . . . . 5

Surface oxidation ........................ 5

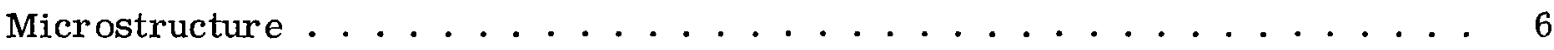

Mechanical Properties ..................... . . 7

Room temperature tensile properties . . . . . . . . . . . . . . 7

Elevated temperature tensile properties................. 8

Elevated temperature creep properties . . . . . . . . . . . . . . 8

Room temperature properties after PAT exposure and creep testing . . . . . . 9

Additional PAT Exposure ....................... 11

SUMMARY OF RESULTS . . . . . . . . . . . . . . . . . . . . . . 11

IMPLICATIONS OF RESULTS . . . . . . . . . . . . . . . . . . . . . . 11

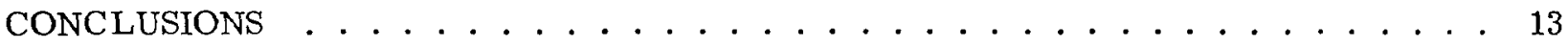

APPENDIXES

A - MECHANICAL PROPERTY DATA FOR OXIDE DISPERSION

STRENGTHENED ALLOYS AND SUPERALLOYS AFTER

PLASMA ARC TUNNEL EXPOSURE . . . . . . . . . . . . . . . . 14

B - ADDITIONAL PLASMA ARC TUNNEL EXPOSURE OF DS-NiCr(I) . . . . . . 15

REFERENCES . . . . . . . . . . . . . . . . . . . . . 17 


\title{
EFFECT OF SIMULATED EARTH REENTRY EXPOSURE ON MECHANICAL PROPERTIES OF SEVERAL OXIDE DIS PERSION STRENGTHENED AND SUPERALLOY SHEET MATERIALS
}

\author{
by J. Daniel Whittenberger \\ Lewis Research Center
}

\author{
SUMMARY
}

The effects of simulated multiple reentry into the Earth's atmosphere on the mechanical properties of several high temperature metallic sheet materials were evaluated. The materials included five thin-gage (nominally 0.025 - and $0.037-\mathrm{cm}$ ) oxide dispersion strengthened (ODS) alloys and two thin-gage (nominally 0.037-cm) superalloys. Multiple reentry conditions were simulated through cyclic Plasma Arc Tunnel (PAT) exposure.

PAT exposure generally consisted of 100 cycles of 600 -second duration at 1255 , 1366 , or $1477 \mathrm{~K}\left(1800^{\circ}, 2000^{\circ}\right.$, or $\left.2200^{\circ} \mathrm{F}\right)$ in a Mach 4.6 air stream with an impact pressure of nominally $800 \mathrm{~N} / \mathrm{m}^{2}$. The superalloys, Haynes Alloy 188 and Hastelloy X, were subjected to the least severe conditions (100 cycles at $1255 \mathrm{~K}$ ); and the ODS alloys, $\mathrm{TD}-\mathrm{NiCrAl}$ and $\mathrm{TD}-\mathrm{NiCrA1Y}$, were subjected to the most severe conditions (100 cycles at $1477 \mathrm{~K}$ ). Intermediate exposures were given to the two ODS alloys that do not contain aluminum, $\mathrm{TD}-\mathrm{NiCr}$ and $\mathrm{DS}-\mathrm{NiCr}$. Mechanical properties of all alloys were determined before and after PAT exposure. Additional analysis included examination of the microstructure and oxide scale of exposed alloys, and fracture surfaces of tested specimens.

PAT exposure produced a uniform oxide scale on all the alloys. In addition, exposure of the aluminum-free alloys resulted in oxide pits or intergranular oxidation, Kirkendall porosity, and alloy depletion zones. Microstructural changes were not observed in the aluminum containing ODS alloys. Within the limits of the PAT exposures evaluated in this study, PAT exposure did not significantly affect the mechanical properties of the thin gage (nominally $0.025-$ or $0.037-\mathrm{cm}$ ) alloys evaluated. Thus it appears that the microstructural changes produced by Plasma Arc Tunnel exposure has little influence on mechanical properties.

Based on the results of this study, the evaluated superalloys and ODS alloys appear to be usable in thermal protection systems for hypersonic reentry conditions providing the design operating parameters are matched to the normal limitations of these alloys. 


\section{INTRODUCTION}

Thin-gage metallic sheet alloys have been considered for use in thermal protection systems (TPS) and related components of reusable hypersonic reentry vehicles, such as the Space Shuttle. In these applications, both high temperature strength and oxidation resistance are required to withstand the stress-temperature-hypervelocity oxidizing conditions encountered during multiple reentry exposures. Previous investigations (refs. 1 to 5 ) have shown that nickel-base and cobalt-base superalloys and oxide dispersion strengthened (ODS) nickel-base alloys have potential for use as TPS materials. However, it was also shown (refs. 1, 2, 3, and 5) that high temperature, high velocity conditions greatly increase the oxidation rate as compared to static testing of the materials which form chromia or chromite spinels. The increased oxidation rates reduced the base metal thickness and increased microstructural damage in the base metal near the oxide/metal interface. The changes in microstructure included development of porosity, alloy depletion, oxide pits, and/or intergranular oxidation. Such behavior is thought to be detrimental for multiple use applications as these effects can reduce the load carrying capacity of the material.

The purpose of this study was to determine the effects of a high temperature-high velocity oxidizing environment on the mechanical properties of several high temperature sheet alloys that are potential candidates for use in metallic thermal protection systems. To accomplish this, seven thin-gage sheet alloys were exposed in a Plasma Arc Tunnel (PAT) which simulates high temperature-hypervelocity reentry conditions. After PAT exposure, the mechanical properties were determined and compared to the sheet alloy properties prior to exposure. Additional analysis included examination of the microstructure and oxide scale of the exposed alloys.

\section{EXPERIMENTAL}

\section{Materials}

Five oxide dispersion strengthened alloys and two superalloys were investigated in this program. The nominal compositions and thickness of these sheet alloys are listed in table I. Three different types of $\mathrm{Ni}-20 \mathrm{Cr}-\mathrm{ThO}_{2}$ alloys were examined. They included TD-NiCr, which was produced by a standardized process involving powder metallurgy techniques and thermomechanical processing (ref. 6); and two DS-NiCr alloys, which were produced by pack chromizing of $\mathrm{Ni}-2 \mathrm{ThO}_{2}$ (ref. 7). The difference between $\mathrm{DS}-\mathrm{NiCr}(\mathrm{I})$ and $\mathrm{DS}-\mathrm{NiCr}(\mathrm{I})$ was in the supplier of the $\mathrm{Ni}-2 \mathrm{ThO}_{2}$ alloy sheet. $\mathrm{DS}-\mathrm{NiCr}(\mathrm{I})$ was produced from DS-Ni (Sherritt-Gordon Mines, Ltd.) while DS-NiCr(II) was produced 
from TD-Ni (Fansteel, Inc.). TD-NiCrAl and TD-NiCrAIY are experimental alloys which were developed as modifications of $\mathrm{Ni}-20 \mathrm{Cr}-2 \mathrm{ThO}_{2}$ in an attempt to improve the oxidation resistance of the base alloy. In making TD-NiCrAlY, yttrium was added in metallic form. However, it is felt that the powder metallurgy techniques involved in sheet manufacture resulted in the yttrium being present as an oxide (private communication from C. P. Blankenship; Lewis Research Center; Cleveland, Ohio). In addition to the dispersion strengthened alloys, the nickel-base alloy Hastelloy $\mathrm{X}$ and the cobaltbase alloy Haynes Alloy 188 were also examined. These alloys are representative of conventional oxidation-resistant superalloy sheet materials.

The microstructure of $\mathrm{TD}-\mathrm{NiCr}$ consisted of pancake-shaped grains approximately $50 \mu \mathrm{m}$ thick and $210 \mu \mathrm{m}$ in diameter (grain aspect ratio $\sim 4$ ). As the unique microstructure of DS-NiCr produced by pack chromizing consists of bands of thoria-free and thoriacontaining regions, grain size parameters were essentially undeterminable. However, from figure 1 it can be seen that $\mathrm{DS}-\mathrm{NiCr}$ (II) had a larger grain size than $\mathrm{DS}-\mathrm{NiCr}(\mathrm{I})$. The grain structure of $\mathrm{TD}-\mathrm{NiCrAl}$ could not be determined as it consisted of very small grains with a low grain aspect ratio. TD-NiCrAlY possessed a duplex microstructure with relatively large grains (probably the result of the secondary grain coarsing effect, (ref. 8) and very fine grains. The large grain regions in TD-NiCrA1Y accounted for less than 15 percent of the total microstructures. Both Hastelloy $\mathrm{X}$ and Haynes Alloy 188 had equiaxed grain structures where the average grain diameters wer $336 \mu \mathrm{m}$ for Hastelloy X and $25 \mu \mathrm{m}$ for Haynes Alloy 188.

All alloys were tested in the as-received surface condition. With the exception of TD-NiCrAl and TD-NiCrAlY, the sheet alloys had metallic finishes - TD-NiCrAl and TD-NiCrAlY had preoxidized surfaces which were developed through the process outlined in reference 9. Such preoxidation was necessary to develop a protective alumina scale. The Ni-20 Cr-2 $\mathrm{ThO}_{2}$ alloys had a nominally 120 grit belt sanded surface finish, and the superalloys had a cold rolled surface finish.

\section{Plasma Arc Tunnel Exposure}

The Plasma Arc Tunnel exposure of the thin sheet alloys was conducted under NASA Contract NAS2-6601 by the Flight Sciences Department of the McDonnell Douglas Research Laboratories, St. Louis, Missouri, under the direction of W. A. Rinehart. Detailed test procedures and results as pertaining to the PAT exposures are reported in reference 10 . In general, nominally 10 - by $10-\mathrm{cm}$ samples were fabricated from the sheet alloys. Each sample was exposed to the high temperature-hypervelocity air stream for either 50 or 100 cycles. Each cycle consisted of 600 seconds in the test stream, followed by 600 seconds out of the test stream. All exposures were conducted 
with the sample surface normal to the air stream, and the entire sample surface was bathed in the test stream. The nominal test conditions involved exposure at 1255, 1366, or $1477 \mathrm{~K}\left(1800^{\circ}, 2000^{\circ}\right.$, and $\left.2200^{\circ} \mathrm{F}\right)$ to a Mach 4.6 air stream with an impact pressure of nominally $800 \mathrm{~N} / \mathrm{m}^{2}$ (6 torr). Sample temperatures were monitored during each test cycle by Pt-Pt/10\% Rh thermocouples which were tack welded to the back of the samples. In general, the sample temperatures were uniform to $\pm \mathbf{5}$ percent. Thickness measurements of each sample were made prior to, at various intervals during, and upon completion of the cyclic exposure. Figure 2 illustrates the front view of a test sample and the approximate locations of the thickness measurements and thermocouple sites. A typical temperature-time profile for a test cycle is shown in figure 3 . With one exception, duplicate samples were exposed for each material-test temperature condition.

As the aluminum modified ODS alloys were thought to possess the best oxidation resistance, they were subjected to the most severe PAT conditions $(100$ cycles at $1477 \mathrm{~K})$. Because of their probable lower oxidation resistance, the superalloys were subjected to the least severe exposure conditions (100 cycles at $1255 \mathrm{~K}$ ). Also, because of their intermediate oxidation resistance, the nominally $\mathrm{Ni}-20 \mathrm{Cr}-2 \mathrm{ThO}_{2}$ alloys were exposed at various conditions ranging from 100 cycles at $1255 \mathrm{~K}$ to 50 cycles at $1477 \mathrm{~K}$.

\section{Postexposure Evaluation}

Following Plasma Arc Tunnel exposure, pin-grip-type tensile specimens were blanked from each PAT sample. The tensile specimens had a $2.5-$ by $0.63-\mathrm{cm}$ gage section where the gage length was perpendicular to the sheet rolling direction. Testing in this direction was chosen as the transverse sheet direction is generally weaker than the longitudinal sheet direction (rolling direction) and perhaps more susceptible to external influences. Five tensile specimens were obtained from each exposed sample. Tensile-type specimens were also blanked from the as-received sheet alloys. In order to remove any residual effects of the blanking operation, the edges of as-punched specimens were dressed down by manual grinding with a rubber-bonded abrasive. This, unfortunately, introduced shallow depressions as deep as $0.01 \mathrm{~cm}$ into the gage section in many test specimens. To remove the influence of the depressions, the gage sections were machine ground to approximately $0.58 \mathrm{~cm}$ in width.

To determine the effects of PAT exposure, mechanical property tests were conducted on as-received and as-exposed alloys. The mechanical property testing included room temperature and elevated temperature tensile tests, elevated temperature creep tests, and room temperature tensile tests after creep testing (residual property tests). All testing was conducted in air. 
Elevated temperature testing was conducted at $1366 \mathrm{~K}$ for the dispersion strengthened alloys and at $1255 \mathrm{~K}$ for the superalloys. The mechanical properties of the exposed specimens were based on the original average thickness of the PAT sample. The mechanical testing was conducted to ASTM Specifications E21-70 and E139-70. Most testing was accomplished under contract NAS3-17168 at Spectrum Laboratories, Inc., Piscataway, New Jersey. Additional testing was completed at the Lewis Research Center. Strains for both elevated temperature tensile and creep tests were measured by an extensometer involving rods which were mechanically attached to the reduced section. Differential motion of the extensometer rods was measured by a linear variable differential transformer (LVDT). The output of the LVDT was continuously recorded. This extensometry system was apparently able to sense strains on the order of 0.0001 over the period of the test.

Other postexposure examinations included analysis of the PAT surface oxides by $\mathrm{X}$-ray diffraction techniques, metallography of the sheet cross section, electron microprobe analysis of the alloy depletion zones. These studies were conducted on blanking scrap from near the center of the exposed samples (position 9, fig. 2). In addition, the fracture surfaces of selected mechanical property test specimens were examined with aid of the scanning electron microscope (SEM).

\section{RESULTS AND DISCUSSION}

\section{Structural Effects of PAT Exposure}

Surface oxidation. - The PAT exposure conditions, average as-received and asexposed thickness, color of the exposed surface, and oxides found on the exposed surface for each alloy are presented in table II. From the thickness data in table II, it can be seen that PAT exposure produced about a 10 percent increase in thickness for all the alloys. This change in thickness is probably due to the buildup of oxide scale, localized protrusions on the oxide scale, and some distortion of the test sample. The copper color observed on the PAT exposed side of many test specimens was found to be due to copper chromate. Copper was apparently injected into the plasma arc stream through erosion of the plasma arc electrode (a 20wt. \% Cu-80wt. \% Ag electrode was used in this work). Data in table II on the oxide phase formed on the PAT-exposed surface indicates that the presence of copper affects the lower temperature oxidation behavior of the $\mathrm{Ni}-20 \mathrm{Cr}-2 \mathrm{ThO}_{2}$ alloys; for example, after exposure to $1366 \mathrm{~K}$, the only surface oxide found was $\mathrm{Cu}_{2} \mathrm{Cr}_{2} \mathrm{O}_{4}$. Normally the surface oxides formed on $\mathrm{Ni}-20 \mathrm{Cr}-2 \mathrm{ThO}_{2}$ alloys would be $\mathrm{NiO}, \mathrm{Cr}_{2} \mathrm{O}_{3}$, and/or spinels (refs. 2 and 5). Copper contamination of the plasma arc stream apparently had no effect on the oxide phase formed on the other alloys 
or TD-NiCr exposed at $1477 \mathrm{~K}$. For similar exposure conditions, the oxide phases observed in this study agree, in general, with those reported in reference 2. However, it should be noted that in this study there is evidence that the foreign metal ions in the plasma arc stream affected the oxidation behavior of some of the exposed alloys. Thus, such PAT exposures may not be truly representative of a reentry into the atmosphere.

Microstructure. - The results of the microstructural study and typical photomicrographs are presented in tables III and IV and figure 4. In general, for the aluminumfree ODS alloys, PAT exposure produced uniform oxide layers on both sides of the sample (figs. 4(a), (b), and (d)), oxide pits (fig. 4(a)) or intergranular oxidation on the PAT-exposed side (fig. 4(d)), zones of alloy depletion behind the oxide scales (table III), and in some instances Kirkendall porosity in the alloy depletion zones (figs. 4(a) and (b) and table III). On the other hand, PAT exposure of the aluminum-containing ODS alloys simply produced a uniform oxide scale on both sides of the sample (fig. 4(c)). No microstructural damage was observed in the aluminum-containing ODS alloys.

Metallography of exposed $\mathrm{Ni}-20 \mathrm{Cr}-2 \mathrm{ThO}_{2}$ alloys indicated that PAT exposure did not affect the grain structure of these alloys; however, PAT exposure did produce drastic microstructural changes near the sheet surfaces (figs. 4(a) and (b)). The data in tables III and IV for TD-NiCr indicate that the degree of microstructural damage increases directly with the temperature of the PAT exposure. It can also be seen in these tables that similar PAT exposure $(100$ cycles at $1366 \mathrm{~K}$ ) can produce differing amounts of microstructural damage in the various $\mathrm{Ni}-20 \mathrm{Cr}-2 \mathrm{ThO}_{2}$ alloys. For example, the DS- NiCr alloys had less Kirkendall porosity and a lower $\mathrm{Cr}$ substrate surface concentration than $\mathrm{TD}-\mathrm{NiCr}$; also, $\mathrm{DS}-\mathrm{NiCr}$ (II) possessed the deepest oxide pits, while DS- $\mathrm{NiCr}(\mathrm{I})$ apparently had no oxide pits. Overall, the microstructures of $\mathrm{Ni}-20 \mathrm{Cr}-\mathrm{ThO}$ alloys after PAT exposure are similar to those reported in references 2 and 5.

PAT exposure of Hastelloy $\mathrm{X}$ and Haynes Alloy 188 at $1255 \mathrm{~K}$ did not affect the grain sizes of these alloys; however, exposure did produce grain boundary and intragranular precipitates in both alloys (fig. 4(d)). These precipitates are apparently the results of thermal effects at $1255 \mathrm{~K}$ as a 16 -hour anneal at $1255 \mathrm{~K}$ produced similar precipitation in both alloys. Data (figs. 1314, 1315, and 1416) in reference 11 indicates that the precipitates in both alloys are probably carbides. PAT exposure of these alloys at $1255 \mathrm{~K}$ also produced a uniform oxide scale, intergranular oxidation, and zones of alloy depletion; however, Kirkendall porosity was not observed. No precipitates were seen in Haynes Alloy 188 after exposure to 50 cycles at $1366 \mathrm{~K}$; however, this exposure did produce grain growth. Unfortunately, the grain size could not be determined due to difficulty in etching. Other microstructural features after this exposure included a thick oxide layer, alloy depletion, and intergranular oxidation. 


\section{Mechanical Properties}

The averaged mechanical properties for TD-NiCr and Haynes Alloy 188 are presented in figures 5 and 6 . In general, the results for these two alloys are typical of those for all the alloys examined. The overall observation of this work is that the PAT exposures evaluated in this study did not significantly affect the mechanical properties of either the ODS alloys or the superalloys in the sheet thickness evaluated. Thus, it appears that the microstructural damage produced by Plasma Arc Tunnel exposures evaluated in this study had little influence on bulk mechanical properties. Below are presented short discussions of the mechanical properties measured in this work. The supporting evidence is contained in figures 5 and 6 and appendix $A$. The latter is a tabular compilation of measured mechanical properties for all the alloys and test conditions evaluated in this study.

Room temperature tensile properties. - Considering only ultimate tensile strengths and tensile elongations, PAT exposure did not greatly influence these properties. Typical examples are shown in figure 5(a). As-received and as-exposed mechanical properties of DS- NiCr(I), DS- NiCr(II), Haynes Alloy 188 (100 cycles at $1255 \mathrm{~K}$ ), and TDNiCrAl were essentially equivalent. Exposure appears to slightly reduce the ultimate tensile strength and elongation of $\mathrm{TD}-\mathrm{NiCr}$ (not statistically significant by "'t' test) and Hastelloy X (statistically significant). Haynes Alloy 188 exposed to 50 cycles at $1366 \mathrm{~K}$ suffered about a 15 percent reduction in ultimate tensile strength (statistically significant); this is probably due to the observed grain growth in this condition and loss of load-bearing area due to oxidation during PAT exposure. TD-NiCrAlY seemingly suffered a 30 percent reduction in ultimate tensile strength after PAT exposure; however, residual property tensile tests of TD-NiCrAlY (see the section Room temperature pi-operties after PAT exposure and creep testing) indicated little, if any, difference between the tensile properties of as-received alloy, creep-tested-as-received material, and creep-tested-PAT-exposed material.

While the room temperature tensile properties indicated that PAT exposure had little effect, scanning electron microscope (SEM) examination of the tensile fracture surfaces revea led microstructural damage in several alloys. The damage observed in PAT-exposed TD-NiCr is particularly striking and can, in some instances, resemble that due to creep effects (refs. 12 and 13) as can be seen in figure 7 . The network of very large fracture dimples in figure $7(\mathrm{a})$ is probably due to ductile fracture mechanism in a region containing a very high concentration of Kirkendall pores. The fracture surface shown in figure $7(\mathrm{~b})$ is more typical of PAT exposed TD-NiCr. The existence of PAT damage in these photomicrographs can be easily seen by a comparison of them to figure $7(\mathrm{c})$ which illustrates the typical fracture surface in as-received $\mathrm{TD}-\mathrm{NiCr}$. Microstructural damage due to PAT exposure was occasionally seen in DS- $\mathrm{NiCr}(\mathrm{I})$ and 
and $\mathrm{DS}-\mathrm{NiCr}$ (II); however, this damage was not as severe as that seen in $\mathrm{TD}-\mathrm{NiCr}$ because of the lower concentration of Kirkendall porosity (table III and ref. 14).

The tabular room temperature tensile data for all alloys and PAT exposure conditions evaluated in this study are presented in appendix $A$. The tensile data include 0.02 percent yield stress, 0.2 percent yield stress, ultimate tensile strength, and tensile elongation.

Elevated temperature tensile properties. - The results of $1366 \mathrm{~K}$ tensile testing of TD-NiCr and $1255 \mathrm{~K}$ tensile testing of Haynes Alloy 188 are shown in figure $5(\mathrm{~b})$. As was the case for room temperature tensile testing, PAT exposure had no significant effect on elevated temperature tensile properties. Prior exposure had essentially no effect on the properties of TD-NiCr, TD-NiCrAl, TD-NiCrAlY, and Haynes Alloy 188. The ultimate tensile strength of $\mathrm{DS}-\mathrm{NiCr}(\mathrm{I})$ and $\mathrm{DS}-\mathrm{NiCr}(\mathrm{II})$ was unaffected by prior exposure; however, the $1366 \mathrm{~K}$ tensile ductility appears to have been reduced about 50 percent in these two alloys. The ductility of $\mathrm{DS}-\mathrm{NiCr}(\mathrm{I})$ seems to be reduced from 2.6 to 1.4 percent through exposure; however, this difference was not found to be statistically significant. On the other hand, the decrease in tensile elongation observed in $\mathrm{DS}-\mathrm{NiCr}$ (II) after PAT exposure (2.3 percent versus 5.2 percent for as-received alloy) is statistically significant. PAT exposure also had little effect on the ultimate tensile strength of Hastelloy $\mathrm{X}$; however, the ductility may be slightly ( 20 percent) reduced.

The tabular elevated temperature tensile data for all alloys and PAT exposures evaluated in this study are presented in appendix A. The data include 0.02 percent yield stress, 0.2 percent yield stress, ultimate tensile strength, and tensile elongation.

Elevated temperature creep properties. - Creep tests were conducted at $1366 \mathrm{~K}$ on the ODS alloys and at $1255 \mathrm{~K}$ on the superalloys; typical results in the form of total plastic creep (time-dependent strain plus plastic strain on loading) are presented for $\mathrm{TD}-\mathrm{NiCr}$ and Haynes Alloy 188 in figure 5(c). As was the case for tensile properties, PAT exposure essentially had no effect on the creep strength properties. In practically all cases, the exposed alloys were at least as strong as the as-received alloys; in fact, most tests indicated that the exposed alloys were more creep resistant than the unexposed alloys. In general, creep in the evaluated alloys systems, particularly the ODS alloys, did not follow the classical three-stage behavior. In many tests, creep consisted of a long period of transient creep followed by a period of essentially no timedependent deformation (steady state creep rate less than $3 \times 10^{-10} \mathrm{sec}^{-1}$ ).

In table $\mathrm{V}$, the average total plastic creep strain after 150 hours of testing (timedependent strain plus plastic strain on loading) is presented as a function of initial stress for each alloy. The data in this table were obtained by averaging the test results for both as-received and PAT-exposed specimens. The three $\mathrm{Ni}-20 \mathrm{Cr}-2 \mathrm{ThO}_{2}$-type alloys exhibited about equal strength, while TD-NiCrAl and TD-NiCrAlY were much weaker. 
These results are in agreement with those in references 6 and 7 with regards to correlations between microstructure and creep strength of ODS alloys. The superiority of the creep strength of $\mathrm{TD}-\mathrm{NiCr}$ in comparison to that of $\mathrm{TD}-\mathrm{NiCrAl}$ and $\mathrm{TD}-\mathrm{NiCr} \mathrm{AlY}$ is due to the differences in microstructure. $\mathrm{TD}-\mathrm{NiCr}$ had a large grain size and a reasonably high grain aspect ratio while both $\mathrm{TD}-\mathrm{NiCr} \mathrm{Al}$ and $\mathrm{TD}-\mathrm{NiCr} \mathrm{AlY}$ had small grain sizes and low grain aspect ratios. Previous work (ref. 6) has shown that both large grain size and large grain aspect ratio are required for high creep strength in the TD-NiCr and TD-NiCrAl systems. The almost equivalent creep strength of TD-NiCr, DS-NiCr(I) and DS-NiCr(II) is more difficult to understand. As can be seen in figures 1 and 4, the microstructures of $\mathrm{DS}-\mathrm{NiCr}$ (I) and $\mathrm{DS}-\mathrm{NiCr}$ (II) are unique and totally different from that of TD-NiCr. From the microstructures in figure 1, it appears that DS-NiCr(I) and DS- $\mathrm{NiCr}$ (II) can be viewed as laminar composites composed of alternating layers of strong material (Ni-20Cr-2 $\mathrm{ThO}_{2}$ ) and weak material (Ni-20Cr). According to references 15 and 16, laminar composites generally have stress-rupture strengths equal to or exceeding the values predicted by the rule-of-mixtures. Since the DS-NiCr-type alloys evaluated had a high volume fraction of thoriated alloy (approximately 80 percent), they should possess good creep strength.

Of the superalloys evaluated, Hastelloy $\mathrm{X}$ appears to be the stronger alloy at $1255 \mathrm{~K}$. The creep strength of Haynes Alloy 188 is similar to that reported in reference 4.

The tabular elevated temperature creep data for all alloys and PAT exposure evaluated in this study are presented in appendix A. The creep data include elastic strain on loading, plastic strain on loading, time required to produce various creep strains, creep strain at end of test, total plastic creep strain at end of test, and approximate steady state creep rate. Again it should be noted that all testing was conducted in the transverse sheet direction which is generally believed to be the weakest direction.

Room temperature properties after PAT exposure and creep testing. - Following elevated temperature creep testing, test specimens were tensile tested at room temperature to obtain residual property data. The data shown in figure 6 for TD-NiCr are typical for an alloy which undergoes creep degradation where prior creep strains as low as 0.1 percent drastically reduce tensile ductility and somewhat reduce ultimate tensile strength. These data seem to indicate that the PAT exposed TD-NiCr was more susceptible to creep damage than the unexposed material (this indeed seems to be the case here on the basis of Scanning Electron Microscope examination of the residual fracture surfaces). However, it should be noted that a previous study (ref. 12) has shown that small amounts of prior elevated temperature creep strain (on the order of 0.1 percent) alone can severely reduce room temperature tensile properties. The difference in residual properties between the unexposed and exposed alloys could be simply due to the great difficulty in accurately measuring small creep strains at elevated temperature. Therefore, until further residual property testing is conducted, it is tentatively con- 
cluded that there is no difference in residual properties between creep tested TD-NiCr and PAT exposed-creep tested TD-NiCr.

On the basis of these mechanical property data, the only ODS alloy that exhibited definite signs of creep degradation was TD-NiCr. However, SEM examination of selected residual property specimens revealed that creep degradation can occasionally occur in $\mathrm{DS}-\mathrm{NiCr}(\mathrm{I})$ and $\mathrm{TD}-\mathrm{NiCr} \mathrm{AlY}$. Examples of creep damage are shown in figure 8. These fractographs are similar to those shown for other creep-damaged ODS alloys (refs. 12 and 13). It should be noted that for $\mathrm{DS}-\mathrm{NiCr}(\mathrm{I})$ only one residual property specimen out of 13 tests suffered creep damage while only three TD-NiCrAlY residual property specimens out of 12 tests were creep damaged. On the other hand, nearly all TD-NiCr residual property specimens (14 out of 17 tests) were found to be creep damaged. The mechanical properties of $\mathrm{DS}-\mathrm{NiCr}$ (II) and $\mathrm{TD}-\mathrm{NiCrAl}$ indicated that these alloys were not creep damaged. SEM examination of selected residual property fracture surfaces for these alloys confirmed the absence of creep damage.

Creep damage in ODS alloys is believed to be due to diffusional creep (refs. 12, 13, and 17). During creep in large grain size ODS alloys, relatively wide $(\sim 1 \mu \mathrm{m})$ dispersoid-free bands are formed around grain boundaries which are perpendicular to the applied stress. During subsequent residual property testing, tensile deformation tends to be confined to the dispersoid-free bands as they are weaker than the dispersion strengthened material. This results in low macroscopic residual tensile ductility. On the other hand, diffusional creep in small grain size ODS material apparently does not result in creep damage (ref. 13), as only very narrow dispersoid-free bands would be formed (band widths on the order of the interparticle spacing). This model agrees with the residual property test results for $\mathrm{TD}-\mathrm{NiCr}$ (large grain size leads to creep damage), TD-NiCrAlY (the few large grains would be potential sites for creep damage), and $\mathrm{TD}-\mathrm{NiCrAl}$ (no creep damage due to the small grain size). While creep in the DS- $\mathrm{NiCr}$ type alloys is not well understood, the almost total absence of creep damage could be due to the laminar microstructure and apparent small grain size within the dispersion strengthened lamella (fig. 1). Perhaps the one instance of creep damage in DS- $\mathrm{NiCr}(\mathrm{I})$ shown in figure $8(\mathrm{~b})$ is due to an abnormally large grain within the DS-NiCr(I) structure.

The residual property data for Haynes Alloy 188 are presented in figure 6 . These data are typical of the two superalloys tested in this study. While the creep tested specimens appear to undergo a significant loss of tensile ductility ( $\sim 50$ percent compared to as-received ductility), this loss of ductility is probably due to carbide precipitation resulting from thermal exposure. Previous work (ref. 18) has shown that thermal exposure of Haynes Alloy 188 and Hastelloy X at $1255 \mathrm{~K}$ significantly reduces ( 50 percent) their room temperature ductility. The ductility loss for the two superalloys reflects itself in the change from intragranular fracture (no thermal exposure) to a partially intergranular fracture (after thermal exposure) as shown in figure 9 for Haynes Alloy 188. 


\section{Additional PAT Exposure}

During the course of this study, one set of DS-NiCr(I) samples were subjected to slightly higher temperatures during PAT exposure than originally planned. The results of this exposure on the microstructure and the mechanical properties of $\mathrm{DS}-\mathrm{NiCr}(\mathrm{I})$ are given in appendix $B$.

\section{SUMMARY OF RESULTS}

A study of the effect of various Plasma Arc Tunnel exposures on five thin-sheet oxide dispersion strengthened alloys and two thin-sheet superalloys has shown the following:

1. Plasma Arc Tunnel exposures can produce microstructural changes in all the evaluated alloys except the nominally $\mathrm{Ni}-16 \mathrm{Cr}-4 \mathrm{Al}$ ODS alloys.

2. Within the limits of this study, the high temperature-hypervelocity-oxidizing conditions encountered during Plasma Arc Tunnel exposure, did not significantly affect the mechanical properties of the nominally $0.025-$ and $0.037-\mathrm{cm}$ thick sheet alloys.

\section{IMPLICATIONS OF RESULTS}

On the basis of mechanical property testing of various ODS alloys and superalloys, it appears that the severe oxidizing conditions encountered during short term-cyclic exposure in a Plasma Arc Tunnel do not significantly affect the properties of these alloys. Although some changes in properties were observed, practically all of these changes could be ascribed to either thermal effects (such as decreases in room temperature ductility of Haynes Alloy 188 and Hastelloy X after being aged at $1255 \mathrm{~K}$ ) or creeprelated effects (such as creep degradation of $\mathrm{TD}-\mathrm{NiCr}$ ). Thus the high temperaturehypervelocity-cyclic oxidizing conditions that are unique to Plasma Arc Tunnel testing do not seem to significantly contribute to the observed mechanical property changes. While some of the alloys did exhibit readily observable microstructural changes as a result of PAT exposure, such changes in microstructure did not affect the mechanical properties of thin-gage (nominally $0.025-$ and $0.037-\mathrm{cm}$ ) alloys.

For hypervelocity-elevated temperature-cyclic conditions involving up to a total of about 16 hours exposure, this study indicates that both superalloys and ODS alloys can be considered as candidates for thermal protection systems. The use of the conventional superalloys is usually preferred, where possible, because of their lower cost and greater base of experience. The superalloys, Haynes Alloy 188 and Hastelloy X, should 
be useful at $1255 \mathrm{~K}$ and possibly even up to $1366 \mathrm{~K}$. But these superalloys, unfortunately, have relatively low creep strength at $1255 \mathrm{~K}$. So the upper use temperature of these alloys is highly dependent on the design stress.

At higher temperatures the more expensive ODS alloys may be required. The $\mathrm{Ni}$-20Cr-type ODS alloys exhibit sufficient resistance to hypervelocity-oxidizing conditions at temperatures up to $1477 \mathrm{~K}$, and they have better creep strength than the superalloys above $\sim 1200 \mathrm{~K}$. However, one of these alloys, $\mathrm{TD}-\mathrm{NiCr}$, definitely suffers microstructural damage during creep. This damage severely reduces subsequent tensile ductility. Such behavior could limit the usefulness of TD-NiCr in creep-type applications. The Ni-16Cr-4Al-type ODS alloys are the most oxidization-resistant of the evaluated alloys. These alloys should be useful in thermal protection systems up to $1477 \mathrm{~K}$ and possibly even higher. However, these alloys have lower creep strength than the Ni-20Cr-type ODS alloy in this temperature range. Also, one of the aluminummodified ODS alloys, TD-NiCrAlY, exhibited some indications of creep degradation effects which could limit its usefulness.

If the requirements for a metallic thermal protection include reasonable creep strength and residual tensile properties as well as resistance to cyclic-hypervelocity conditions between about $1255 \mathrm{~K}$ and $1477 \mathrm{~K}$, a fine grain size aluminum modified ODS alloy such as TD-NiCrAl, would be a good choice. If a slightly higher creep strength is necessary, then ODS alloys possessing laminar microstructures similar to the DS- NiCrtype alloys should be adequate. Totally or partially large grain size ODS alloys, like $\mathrm{TD}-\mathrm{NiCr}$ and $\mathrm{TD}-\mathrm{NiCrA1Y}$, could also be used if design criteria is based on minimal $(<0.1$ percent) creep deformation in order to retain full residual tensile properties. At lower temperatures up to about $1255 \mathrm{~K}$, either of the two evaluated superalloys, Haynes Alloy 188 or Hastelloy $\mathrm{X}$, should be usable in thermal protection systems providing their creep strengths are adequate to meet operating conditions.

Based on the results of this study, it appears that cyclic-elevated temperaturehypervelocity oxidizing conditions expected in multiple reentry conditions should not present any special problems for the use of either superalloy or ODS alloy sheet material in thermal protection systems. In general, the usual creep-limiting criteria associated with the use of these alloys can be applied in designing thermal protection systems involving these alloys. However, it should be noted that some ODS alloys (those possessing a large grain size) suffer microstructural damage during creep, and this damage can severely reduce the tensile ductility. 


\section{CONCLUSIONS}

Superalloys and oxide dispersion strengthened alloys appear to be usable in thermal protection systems for hypervelocity reentry conditions providing that the design operating conditions are matched to the normal limitations of these alloys.

\section{Lewis Research Center,}

National Aeronautics and Space Administration, Cleveland, Ohio, March 7, 1977, 505-01. 


\section{APPENDIX A}

\section{MECHANICAL PROPERTY DATA FOR OXIDE DISPERSION STRENGTHENED}

\section{ALLOYS AND SUPERALLOYS AFTER PLASMA ARC TUNNEL EXPOSURE}

The room temperature tensile properties, elevated temperature tensile properties, elevated temperature creep properties, and room temperature residual tensile properties for as-received and Plasma Arc Tunnel exposed TD-NiCr, DS-NiCr(I), DS-NiCr(II), TD-NiCrAl, TD-NiCrAlY, Haynes Alloy 188, and Hastelloy X are tabulated in tables VI to XII. Again it should be noted that all mechanical property tests were conducted in the transverse sheet direction which is generally thought to be weaker than the longitudinal (rolling) direction. Also, all the mechanical properties of Plasma Arc Tunnel exposed alloys were calculated on the basis of the average thickness of the Plasma Arc Tunnel samples prior to exposure. 


\section{APPENDIX B}

\section{ADDITIONAL PLASMA ARC TUNNEL EXPOSURE OF DS-NiCr(I)}

During the initial phase of the Plasma Arc Tunnel (PAT) exposures, sample temperatures were monitored by spring loaded thermocouples instead of task welded thermocouples. In the course of PAT exposure, a large difference between the temperature of the sample as measured by means of the spring loaded thermocouples (low readings) and pyrometry (high readings) was observed. This lead to experiments (ref. 10) which established that spring loaded thermocouples were recording temperatures considerably below $(\sim 100 \mathrm{~K})$ those recorded by tack welded thermocouples in the temperature range of interest.

One set of $\mathrm{DS}-\mathrm{NiCr}(\mathrm{I})$ samples were subjected to 40 cycles where spring load thermocouples were employed to record the temperature. On the basis of pyrometry it is estimated that these 40 cycles occurred at approximately $1477 \mathrm{~K}$ rather than the $1366 \mathrm{~K}$ monitored by the spring loaded thermocouples. Following the initial 40 cycles the spring loaded thermocouples were replaced by tack welded thermocouples, and an additional 60 cycles at $1366 \mathrm{~K}$ were conducted. The characteristics of the exposed samples and metallographic and alloy depletion data for these samples are as follows:

Alloy: DS-NiCr(I)

Exposure: $\quad 40$ cycles $-1477 \mathrm{~K}$ plus 60 cycles $-1366 \mathrm{~K}$

Average thickness, Initial - 300

$\mu \mathrm{m}: \quad$ Final -343

Color of exposed Velvet black and copper

surface:

Phases on exposed surface:

$\mathrm{Cu}_{2} \mathrm{Cr}_{2} \mathrm{O}_{4}$

Thickness of uniform PAT side -3

oxide, $\mu \mathrm{m}$ : Back side -1

Maximum depth of $\quad$ PAT side -15

oxide pits into Back side - 0

base metal, $\mu \mathrm{m}$ :

Depth of Kirkendall PAT side -16

porosity, $\mu \mathrm{m}$ : $\quad$ Back side -0 
Cr depletion zone behind uniform oxide:

Cr depletion zone behind oxide pits:
PAT side - distance $75 \mu \mathrm{m}$; approximate substrate surface concentration 12 percent

Back side - distance $55 \mu \mathrm{m}$; approximate substrate surface concentration 19 percent

Distance $65 \mu \mathrm{m}$; approximate substrate surface concentration 15 percent

As can be seen in table XIII, this PAT exposure had no significant effect on the mechanical properties. 


\section{REFERENCES}

1. Johnson, James R.; and Ashbrook, Richard L.: Oxidation and Thermal Fatigue Cracking of Nickel- and Cobalt-Base Alloys in a High Velocity Gas Stream. NASA TN D-5376, 1969.

2. Centolanzi, Frank J.; et al.: Arc Jet Tests of Metallic TPS Materials. NASA TM $\mathrm{X}-62092,1971$.

3. Lowell, Carl E.; and Sanders, William A.: Mach 1 Oxidation of Thoriated Nickel Chromium at $1204^{\circ} \mathrm{C}\left(2200^{\circ} \mathrm{F}\right)$. Oxid. Met., vol. 5, no. 3, Dec. 1972, pp. 221239.

4. Davis, J. W.: Effect of Multiple Entry on the Properties of Superalloys. Proc. Natl. Tech. Conf. on Space Shuttle Materials. Soc. Aerosp. Mater. Process Eng., 1971, pp. 335-345.

5. Tenney, D. R.; Young, C. T.; and Herring, H. W.: Oxidation Behavior of TDNiCr in a Dynamic High Temperature Environment. Metall. Trans., vol. 5, no. 5, May 1974, pp. 1001-1012.

6. Klingler, L. J.; et al.: Development of Dispersion Strengthened Nickel-Chromium Alloy $\left(\mathrm{Ni}-\mathrm{Cr}-\mathrm{ThO}_{2}\right.$ ) Sheet for Space Shuttle Vehicles, Part I. (Fansteel, Inc.; NAS3-13490) NASA CR-120796, 1971.

7. Cook, R. C.; and Norris, L. F.: Process Development for $\mathrm{Ni}-\mathrm{Cr}-\mathrm{ThO} \mathrm{O}_{2}$ and $\mathrm{Ni}-\mathrm{Cr}-\mathrm{Al}-\mathrm{ThO}_{2}$ Sheet. (Sherritt Gordon Mines, Ltd. ; NAS3-14313) NASA CR$134484,1973$.

8. Cairns, R. L.: Effect of Annealing on Structure and Properties of a Dispersion Strengthened Superalloy, IN-853. Metall. Trans., vol. 5, no. 7, July 1974, pp. 1677-1684.

9. Baranow, S.: The Effect of a Hydrogen Preheat-Treatment on the Oxidation Behavior of Ni-Cr-A1-ThO ${ }_{2}$ Alloys. Metall. Trans., vol. 3, no. 12, Dec. 1972, pp. 3265-3267.

10. Rinehart, W. A. ; et al.: Cyclical Tests of Selected Space Shuttle TPS Metallic Materials in a Plasma ARC Tunnel. Volume 1: Description of Tests and Program Summary. (MDC-00473-Vol-1, McDonnell-Douglas Corp.; NAS2-6601) NASA CR-114459, 1972.

11. Lyman, Taylor, ed.: Metals Handbook. Volume 7 - Atlas of Microstructures of Industrial Alloys. Am. Soc. Met., 1972. 
12. Whittenberger, John D.: Observations on the Relationship of Structure to the Mechanical Properties of Thin TD-NiCr Sheet. Metall. Trans., vol. 7A, no. 5, May 1976, pp. 611-619.

13. Whittenberger, J. D. : Creep Degradation in Oxide Dispersion Strengthened Alloys. NASA TN D-8421, 1977.

14. Whittenberger, John D.: An Observation of the Effect of Grain Structure on the Appearance of Kirkendall Porosity. Metall. Trans., vol. 3, no. 11, Nov. 1972, pp. 3038-3040.

15. Hoffman, C. A.; and Weeton, J. W.: Metal-Metal Laminar Composites for High Temperature Applications. NASA TM X-68056, 1972.

16. Hoffman, Charles A.; and Weeton, John W.: A Study of Stress-Rupture and Ductility Properties of Thin Laminal Composites. Metall. Trans., vol. 5, no. 1, Jan. 1974, pp. 309-312.

17. Whittenberger, John D.: Diffusional Creep and Creep Degradation in DispersionStrengthened Ni-Cr Base Alloys. Metall. Trans., vol. 4, no. 6, June 1973, pp. $1475-1483$.

18. Royster, Dick M.; and Lisagor, W. Barry: Effect of High-Temperature Creep and Oxidation on Residual Room-Temperature Properties for Several Thin-Sheet Superalloys. NASA TN D-6893, 1973. 
TABLE I. - NOMINAL COMPOSITIONS AND THICKNESS OF SHEET ALLOYS

\begin{tabular}{|c|c|c|}
\hline Material & Composition, wt. \% & Thickness, cm \\
\hline TD-NiCr (Heat 3634) & $\mathrm{Ni}-19.8 \mathrm{Cr}-2.15 \mathrm{ThO}_{2}$ & 0.025 \\
\hline DS-NiCr(I) & $\mathrm{Ni}-20 \mathrm{Cr}-1.9 \mathrm{ThO}_{2}$ & .025 \\
\hline $\mathrm{DS}-\mathrm{NiCr}$ (II) & $\mathrm{Ni}-20 \mathrm{Cr}-1.9 \mathrm{ThO}_{2}$ & .037 \\
\hline TD-NiCrAl (Heat 3740) & $\mathrm{Ni}-16 \mathrm{Cr}-3.3 \mathrm{Al}-2 \mathrm{ThO}_{2}$ & .037 \\
\hline TD-NiCrAlY (Heat 3741) & $\mathrm{Ni}-16 \mathrm{Cr}-3.4 \mathrm{Al}-0.2 \mathrm{Y}-2 \mathrm{ThO}_{2}$ & .037 \\
\hline $\begin{array}{l}\text { Hastelloy X } \\
\text { (Heat 2600-9-4954) }\end{array}$ & $\mathrm{Ni}-22 \mathrm{Cr}-18.5 \mathrm{Fe}-9 \mathrm{Mo}-2.5 \mathrm{Co}-0.6 \mathrm{~W}$ & 037 \\
\hline $\begin{array}{l}\text { Haynes Alloy } 188 \\
\quad \text { (Heat } 1880-9-0150)\end{array}$ & $\mathrm{Co}-22 \mathrm{Cr}-22 \mathrm{Ni}-14 \mathrm{~W}-1.5 \mathrm{Fe}-0.08 \mathrm{La}$ & .037 \\
\hline
\end{tabular}

TABLE II. - EXTERIOR FEATURES OF PLASMA ARC T UNNEL EXPOSED SAMPLES

\begin{tabular}{|c|c|c|c|c|c|}
\hline \multirow[t]{2}{*}{ Material } & \multirow[t]{2}{*}{ Exposure conditions } & \multicolumn{2}{|c|}{ Average thickness, $\mu \mathrm{m}$} & \multirow{2}{*}{$\begin{array}{l}\text { Color of PAT ex- } \\
\text { posed surface }\end{array}$} & \multirow{2}{*}{$\begin{array}{c}\text { Oxide phases on PAT } \\
\text { exposed surface }\end{array}$} \\
\hline & & As-received & As-exposed & & \\
\hline \multirow[t]{3}{*}{$\mathrm{TD}-\mathrm{NiCr}$} & 100 cycles - $1255 \mathrm{~K}$ & 280 & 318 & $\begin{array}{l}\text { Velvet black and } \\
\text { copper }\end{array}$ & $\mathrm{NiO}, \mathrm{Cu}_{2} \mathrm{Cr}_{2} \mathrm{O}_{4}$ \\
\hline & 100 cycles $-1366 \mathrm{~K}$ & 274 & 292 & $\begin{array}{l}\text { Velvet black and } \\
\text { copper }\end{array}$ & $\mathrm{Cu}_{2} \mathrm{Cr}_{2} \mathrm{O}_{4}$ \\
\hline & 50 cycles $-1477 \mathrm{~K}$ & 283 & 318 & $\begin{array}{l}\text { Black and mottled } \\
\text { green }\end{array}$ & $\mathrm{NiO}, \mathrm{Cr}_{2} \mathrm{O}_{3}$, spinel \\
\hline $\mathrm{DS}-\mathrm{NiCr}(\mathrm{I})$ & 100 cycles $-1366 \mathrm{~K}$ & 299 & 327 & $\begin{array}{l}\text { Velvet black and } \\
\text { copper }\end{array}$ & $\mathrm{Cu}_{2} \mathrm{Cr}_{2} \mathrm{O}_{4}$ \\
\hline $\mathrm{DS}-\mathrm{NiCr}(\mathrm{II})$ & 100 cycles - $1366 \mathrm{~K}$ & 412 & 437 & $\begin{array}{l}\text { Velvet black and } \\
\text { copper }\end{array}$ & $\mathrm{Cu}_{2} \mathrm{Cr}_{2} \mathrm{O}_{4}$ \\
\hline TD-NiCrAl & 100 cycles - $1477 \mathrm{~K}$ & 387 & 406 & $\begin{array}{c}\text { Gray and scattered } \\
\text { areas of black }\end{array}$ & $\alpha-\mathrm{Al}_{2} \mathrm{O}_{3}$, spinel \\
\hline TD-NiCrAlY & 100 cycles $-1477 \mathrm{~K}$ & 344 & 368 & $\begin{array}{c}\text { Gray and scattered } \\
\text { areas of black }\end{array}$ & $\alpha-\mathrm{Al}_{2} \mathrm{O}_{3}$, spinel \\
\hline Hastelloy $\mathrm{X}$ & 100 cycles $-1255 \mathrm{~K}$ & 415 & 463 & $\begin{array}{c}\text { Velvet black and } \\
\text { grayish black }\end{array}$ & $\mathrm{NiO}$, spinel \\
\hline Haynes Alloy 188 & $\begin{array}{r}100 \text { cycles }-1255 \mathrm{~K} \\
50 \text { cycles }-1366 \mathrm{~K}^{\mathrm{a}}\end{array}$ & $\begin{array}{l}362 \\
404\end{array}$ & $\begin{array}{l}409 \\
455\end{array}$ & $\begin{array}{l}\text { Velvet black and } \\
\text { touches of green } \\
\text { Velvet black }\end{array}$ & $\begin{array}{l}\text { spinel } \\
\text { spinel, CoO }\end{array}$ \\
\hline
\end{tabular}

\footnotetext{
${ }^{\text {a }}$ Single PAT sample.
} 
TABLE III. - MICROSTRUCTURAL FEATURES ASSOCIATED WITH PLASMA ARC TUNNEL EXPOSURE [Average data from two metallographic specimens.]

\begin{tabular}{|c|c|c|c|c|c|c|}
\hline \multirow[t]{2}{*}{ Alloy } & \multirow[t]{2}{*}{ Exposure } & \multicolumn{2}{|c|}{$\begin{array}{l}\text { Thickness of uni- } \\
\text { form oxide, } \\
\mu \mathrm{m}\end{array}$} & \multirow{2}{*}{$\begin{array}{c}\text { Maximum depth of } \\
\text { oxide pit(s) into } \\
\text { base metal, } \\
\mu \mathrm{m}\end{array}$} & \multicolumn{2}{|c|}{$\begin{array}{c}\text { Depth of Kirkendall } \\
\text { porosity, } \\
\mu \mathrm{m}\end{array}$} \\
\hline & & PAT side & Back side & & PAT side & Back side \\
\hline \multirow{3}{*}{$\mathrm{TD}-\mathrm{NiCr}$} & 100 cycles $-1255 \mathrm{~K}$ & 13 & 7 & 0 & 13 & 13 \\
\hline & 100 cycles $-1366 \mathrm{~K}$ & 8 & 3 & 13 & 43 & 15 \\
\hline & 50 cycles $-1477 \mathrm{~K}$ & 4 & 1 & 42 & 80 & 45 \\
\hline $\mathrm{DS}-\mathrm{NiCr}(\mathrm{I})$ & 100 cycles $-1366 \mathrm{~K}$ & 12 & 1 & 0 & 16 & 0 \\
\hline DS-NiCr(II) & 100 cycles $-1366 \mathrm{~K}$ & 9 & 1 & 34 & 20 & 7 \\
\hline TD-NiCrAI & 100 cycles $-1477 \mathrm{~K}$ & 3 & 1 & 0 & 0 & 0 \\
\hline TD-NiCrAIY & 100 cycles $-1477 \mathrm{~K}$ & 3 & 1 & 0 & 0 & 0 \\
\hline Hastelloy $\mathrm{X}$ & 100 cycles $-1255 \mathrm{~K}$ & 20 & 2 & $a_{15}$ & 0 & 0 \\
\hline \multirow[t]{2}{*}{ Haynes Alloy 188} & 100 cycles $-1255 \mathrm{~K}$ & 10 & 2 & $a_{15}$ & 0 & 0 \\
\hline & 50 cycles $-1366 \mathrm{~K}$ & 44 & 3 & $a_{25}$ & 0 & 0 \\
\hline
\end{tabular}

${ }^{a}$ Maximum depth of intergranular oxidation. 
TABLE IV. - ALLOY DEPLETION OF PLASMA ARC TUNNEL EXPOSED MATERIALS

\begin{tabular}{|c|c|c|c|c|c|c|c|c|}
\hline \multirow[t]{3}{*}{ Alloy } & \multirow[t]{3}{*}{ Exposure } & \multicolumn{5}{|c|}{ Alloy depletion zones behind uniform oxide scale } & \multicolumn{2}{|c|}{ Depletion zone behind oxide pits } \\
\hline & & \multirow{2}{*}{$\begin{array}{c}\text { Element(s) } \\
\text { analyzed }\end{array}$} & \multicolumn{2}{|c|}{ Distance, $\mu \mathrm{m}$} & \multicolumn{2}{|c|}{ Surface concentration, wt. $\%$} & \multirow{2}{*}{$\begin{array}{c}\text { Distance, } \\
\mu \mathrm{m}\end{array}$} & \multirow{2}{*}{$\begin{array}{c}\text { Approximate substrate } \\
\text { surface concentra- } \\
\text { tion, } \\
\text { wt. } \%\end{array}$} \\
\hline & & & PAT side & Back side & PAT side & Back side & & \\
\hline \multirow[t]{3}{*}{$\mathrm{TD}-\mathrm{NiCr}$} & 100 cycles $-1255 \mathrm{~K}$ & $\mathrm{Cr}$ & 25 & 15 & 13 & 16 & -- & -- \\
\hline & 100 cycles $-1366 \mathrm{~K}$ & $\mathrm{Cr}$ & 70 & 40 & 12 & 18 & 55 & 16 \\
\hline & 50 cycles $-1477 \mathrm{~K}$ & $\mathrm{Cr}$ & 105 & 45 & 10 & 18 & 80 & 17 \\
\hline $\mathrm{DS}-\mathrm{NiCr}(\mathrm{I})$ & 100 cycles $-1366 \mathrm{~K}$ & $\mathrm{Cr}$ & 85 & 40 & 8 & 19 & -- & -- \\
\hline $\mathrm{DS}-\mathrm{NiCr}$ (II) & 100 cycles $-1366 \mathrm{~K}$ & $\mathrm{Cr}$ & 65 & 40 & 9 & 16 & 40 & 12 \\
\hline TD-NiCrAl & 100 cycles $-1477 \mathrm{~K}$ & $\mathrm{Cr} / \mathrm{Al}$ & 0 & 0 & $16 / 3.3$ & $16 / 3.3$ & -- & -- \\
\hline TD-NiCrAlY & 100 cycles $-1477 \mathrm{~K}$ & $\mathrm{Cr} / \mathrm{Al}$ & 0 & 0 & $16 / 3.4$ & $16 / 3.4$ & - & -- \\
\hline Hastelloy $\mathrm{X}$ & 100 cycles $-1255 \mathrm{~K}$ & $\mathrm{Cr}$ & 20 & 15 & 10 & 15 & -- & -- \\
\hline \multirow[t]{2}{*}{ Haynes Alloy 188} & 100 cycles $-1255 \mathrm{~K}$ & $\mathrm{Cr} / \mathrm{Ni}$ & 20 & 15 & $14 / 27$ & $18 / 24$ & -- & -- \\
\hline & 50 cycles $-1366 \mathrm{~K}$ & $\mathrm{Cr} / \mathrm{Ni}$ & 35 & 20 & $14 / 27$ & $19 / 24$ & -- & -- \\
\hline
\end{tabular}


TABLE V. - AVERAGE CREEP STRENGT HS OF TESTED ALLOYS (AVERAGE OVER AS-RECEIVED AND PLASMA ARC TUNNEL EXPOSED ALLOYS)

[All tests transverse to sheet rolling direction.]

\begin{tabular}{|c|c|c|c|c|c|c|c|c|c|}
\hline \multirow[t]{3}{*}{ Alloy } & \multirow{3}{*}{$\begin{array}{c}\text { Test temper- } \\
\text { ature, } \\
\text { K }\end{array}$} & \multicolumn{8}{|c|}{ Stress, $\mathrm{MPa}$} \\
\hline & & 6.9 & 10.3 & 13.8 & 17.2 & 20.7 & 24.1 & 27.6 & 34.5 \\
\hline & & \multicolumn{8}{|c|}{ Average total plastic creep strain after 150 hours, percent } \\
\hline $\mathrm{TD}-\mathrm{NiCr}$ & 1366 & --- & 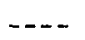 & $-\ldots$ & $-\cdots$ & 0.11 & ----- & 0.19 & 1.1 \\
\hline $\mathrm{DS}-\mathrm{NiCr}(\mathbf{I})$ & 1366 & $-\cdots$ & --- & 0.15 & --- & 0.22 & $-\ldots-$ & 0.32 & -- \\
\hline $\mathrm{DS}-\mathrm{NiCr}(\mathrm{II})$ & 1366 & --- & --- & 0.10 & $-\cdots-$ & 0.21 & ----- & 0.16 & -- \\
\hline TD-NiCrAl & 1366 & ---- & 0.13 & 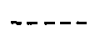 & 0.22 & --- & $>10$ & ---- & -- \\
\hline TD-NiCrAlY & 1366 & $-\cdots$ & 0.17 & --- & 0.26 & --- & 0.65 & --- & -- \\
\hline Haynes Alloy 188 & 1255 & 0.16 & 0.31 & ${ }^{\mathrm{a}} 6.0$ & --- & $--n$ & -...- & --- & --- \\
\hline Hastelloy $\mathrm{X}$ & 1255 & 0.15 & 0.21 & 0.27 & --- & ---- & $-\ldots$ & ---- & --- \\
\hline
\end{tabular}

$\mathrm{a}_{\text {See table XI(c). }}$ 
TABLE VI. - ME CHANICAL PROPERTIES OF AS-RECETVED AND AS-EXPOSED TD-NiCr

(a) Room temperature properties

\begin{tabular}{|c|c|c|c|c|}
\hline \multirow[b]{3}{*}{ Exposuen } & \multicolumn{3}{|c|}{ EXPOS URE } & \\
\hline & $\begin{array}{l}A<-R E C E \\
1=0 \mathrm{CYCL} \\
1=0 \mathrm{CYCl} \\
5 \mathrm{C} \text { CYCL }\end{array}$ & $\begin{array}{l}-1255 \mathrm{~K} \\
-1360 \mathrm{~K} \\
1477 \mathrm{~K}\end{array}$ & & \\
\hline & $\begin{array}{l}\text { D.QP PERCENT } \\
\text { YIELD STRESS, } \\
\text { MFGAPASCALS }\end{array}$ & $\begin{array}{l}\text { Y.Z PEPCENT } \\
\text { YIFLE STRESS, } \\
\text { MECAPASCALS }\end{array}$ & $\begin{array}{l}\text { ULTIMATE TENSILE } \\
\text { STPESS } \\
\text { MEGAPASCALS }\end{array}$ & $\begin{array}{l}\text { ELONCATION IN } \\
2.5 \text { CENTIMETERS, } \\
\text { PERCENT }\end{array}$ \\
\hline $\begin{array}{l}1 \\
1 \\
1 \\
2 \\
2 \\
3 \\
3 \\
4 \\
4\end{array}$ & $\begin{array}{l}330.8 \\
298.7 \\
279.7 \\
567.7 \\
466.8 \\
410.8 \\
332.7 \\
377.8 \\
401.1\end{array}$ & $\begin{array}{l}409.5 \\
54=.4 \\
545.7 \\
658.3 \\
546.0 \\
62^{7} .1 \\
529.3 \\
587.3 \\
527 . ?\end{array}$ & $\begin{array}{l}797.4 \\
854.3 \\
826.8 \\
775.6 \\
757.6 \\
741.9 \\
805.6 \\
796.8 \\
777.6\end{array}$ & $\begin{array}{r}16.0 \\
10.0 \\
9.0 \\
13.0 \\
13.0 \\
6.5 \\
12.0 \\
11.1 \\
a_{6} .5\end{array}$ \\
\hline & & AVEPAGE VAL & & \\
\hline 1 & 723.1 & $52^{2} \cdot 5$ & 026.2 & 11.7 \\
\hline 2 & 517.2 & 622.6 & 766.6 & 13.0 \\
\hline 3 & 371.6 & 561.7 & 771.2 & 9.2 \\
\hline 4 & 389.5 & 555.1 & $7 \times 7.2$ & 8.8 \\
\hline
\end{tabular}

${ }^{\mathrm{a}}$ Fracture at region where very deep oxide penetration occurs. 
TABLE VI. - Continued.

(b) $1366 \mathrm{~K}$ tensile properties

EYPOSURT SYMTCL

AC-RECLIVEO
IEC CYCLCS-1205K
1 CYCLSS-1366K
5-CYCLES-1477K

Exposure

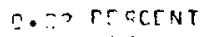
VIELUS STEEST

$\therefore$ Pegctht

STREST.

ILONCATION IN

55.8
75.8
75.0
121.3
73.9
72.2
83.3
81.2
27.9
57.2

89.3
95.9
77.8
171.7
78.5
77.9
97.8
89.2
96.7
107.7

22.3

95.8

77.

134.3

7.0 .8
$7=0.8$

8.8

$8 \in .6$

NEDAGE VALUFS

177.9

TEEENT

$\varepsilon:$

$9-\cdot 1$

0.1

1.0

1.0

1.0
.9

$7 \cdot 2$

71.5

74.0

76.4

1.2

F.2.2

Bt. 1

26.2

$1=2.5$

.4

$42 \cdot t$

1โ2:- 
TABLE VI. - Continued.

(c) $1366 \mathrm{~K}$ creep strength properties

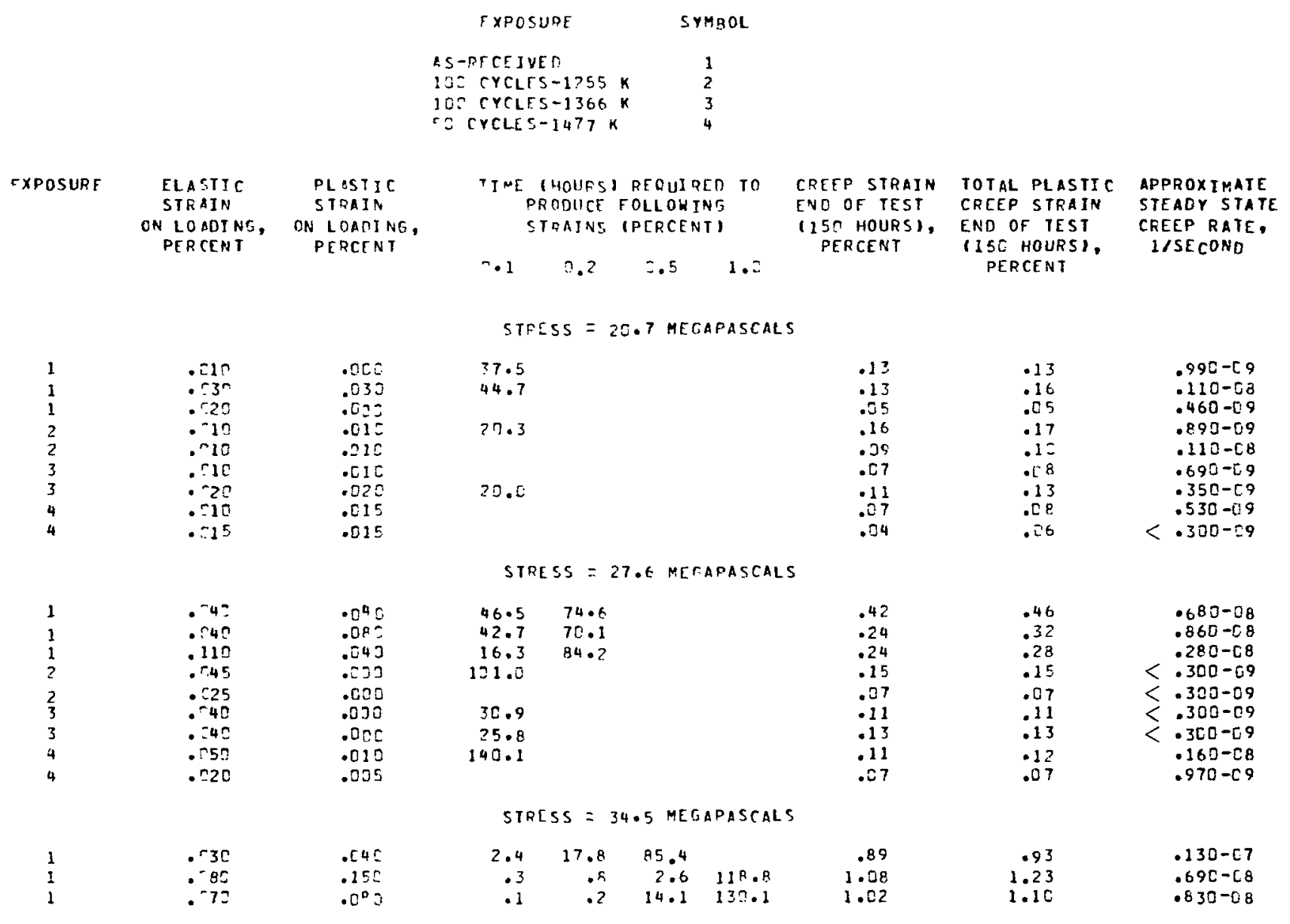


(d) Room temperature residual tensile properties after creep testing at $1366 \mathrm{~K}$

\begin{tabular}{|c|c|}
\hline $\begin{array}{c}\text { PLASM ARC TUNNEL } \\
\text { FXPOSURE }\end{array}$ & SYMROL \\
\hline $\begin{array}{l}\text { AS RECEIVED } \\
\text { IOC CYCLES-1255 }\end{array}$ & $\frac{1}{2}$ \\
\hline $\begin{array}{l}100 \text { rYCLFS-1366 } \\
50 \text { CYCLES }-1477 \mathrm{~K}\end{array}$ & $\begin{array}{l}3 \\
4\end{array}$ \\
\hline
\end{tabular}

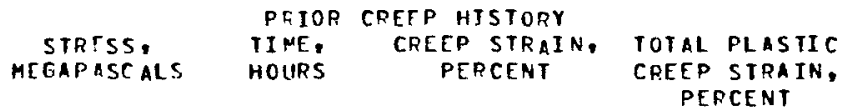

NOT CREEP TESTED NOT CREEP TESTED NOT CREEP TESTED NOT CREEP TESTED NOT CREEP TESTEO NOT CRTCP TESTFD NOT CRTEP TESTFD NOT CREEP TESTTD

$$
\begin{aligned}
& 1 \\
& 1 \\
& 2 \\
& 2 \\
& 3 \\
& 3 \\
& 4 \\
& 4
\end{aligned}
$$$$
20.7
$$$$
\begin{aligned}
& 20.7 \\
& 20.7
\end{aligned}
$$$$
\begin{aligned}
& 20.7 \\
& 20.7
\end{aligned}
$$$$
\begin{aligned}
& 20.7 \\
& 20.7
\end{aligned}
$$$$
20.7
$$$$
\begin{aligned}
& 20.7 \\
& 20.7
\end{aligned}
$$

$$
155 \cdot 0
$$$$
\begin{aligned}
& 15 \% .0 \\
& 150.0
\end{aligned}
$$$$
15 ? .0
$$$$
150.3
$$$$
150.0
$$$$
155.0
$$

$$
\begin{aligned}
& .13 \\
& .05 \\
& .16 \\
& .09 \\
& .07 \\
& .11 \\
& .07
\end{aligned}
$$$$
27.6 \quad 155.0
$$$$
27.6 \quad 150.0
$$$$
27.6 \quad 150.0
$$$$
27.6 \quad 15 \mathrm{r.3}
$$$$
27.6 \quad 150.0
$$$$
27.6 \quad 15.0
$$$$
\begin{array}{ll}
27.6 & 150.0 \\
27.6 & 150.0
\end{array}
$$$$
.07
$$$$
\begin{aligned}
& .24 \\
& .24 \\
& .15 \\
& .07 \\
& .11 \\
& .13 \\
& .11 \\
& .07
\end{aligned}
$$$$
150.0
$$

1.08

34.4

150.0

1.23
RESIRUAL TENSTLE PROPERTIES O.2 PERCTNT, UETIIMATE ELONCATION,
YIELO SIPESS, TENSILE STRESS, PERCENT
MEGAPASCALS MEGAPASCALS

$\begin{array}{llr}487.1 & 791.7 & 16.0 \\ 540.2 & 854.4 & 10.0 \\ 546.4 & 826.8 & 9.0 \\ 661.4 & 779.3 & 13.0 \\ 549.1 & 761.3 & 13.0 \\ 625.6 & 745.5 & 6.5 \\ 502.3 & 803.4 & 12.0 \\ 587.0 & 796.5 & 11.1 \\ 523.0 & 777.9 & a_{6.5}\end{array}$

562.2

556.0
590.5

596.0

537.4

541.6

505.0

496.1

540.9

516.7

457.5

573.9

612.1

645.8

557.1
.0

\section{3}

758.6
667.6

680.7

622.2

638.7

553.3

10.2
$1 ? .0$

b. 9

b. 9

$b_{2} \cdot 8$
$b_{0} .9$

$b_{1}: 9$

494.7

\section{5}

686.2

458.9

650.6

650.6

770.4

531.9

$b_{2.8}$
$c_{3.7}$
$b_{1.0}$
$b_{1} .0$
$b_{1} .3$
$b_{3.7}$
$b_{1.9}$
$b_{1.0}$
$b_{.9}$

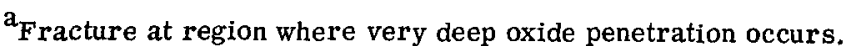

${ }^{\mathrm{b}}$ Creep damaged.

Out of gage failure. 
TABLE VII. - MECHANICAL PROPERTIES OF AS-RECEIVED AND PLASMA ARC TUNNEL EXPOSED DS-NiCr(I)

(a) Room temperature tensile properties

\begin{tabular}{|c|c|c|c|c|}
\hline \multirow[b]{3}{*}{ EXPCSUar } & \multicolumn{3}{|c|}{ rYFTE URE } & \multirow[b]{3}{*}{$\begin{array}{l}\text { TLONCATIINN I'H } \\
\text { ? E CENTIMETERS, } \\
\text { PERCLNT }\end{array}$} \\
\hline & \multicolumn{2}{|c|}{ A:-2ECE:VEO } & $?$ & \\
\hline & $\begin{array}{l}\text { J.ZZ PEFCTN' } \\
\text { YITLE STRESS, } \\
\text { MFFAPASCALS }\end{array}$ & 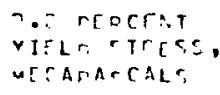 & $\begin{array}{l}\text { ULTIMATF TE USILS } \\
\text { STOESS, } \\
\text { MEGAFASCALS }\end{array}$ & \\
\hline $\begin{array}{l}1 \\
1 \\
1 \\
1 \\
2\end{array}$ & $\begin{array}{l}5.6 .6 .4 \\
548.4 \\
407.8 \\
5,72.3 \\
2 \times 2.5\end{array}$ & 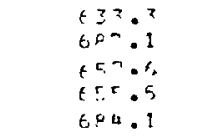 & $\begin{array}{l}788.6 \\
849.5 \\
862.5 \\
823.1 \\
904.6\end{array}$ & $\begin{array}{l}15.7 \\
13.9 \\
16.7 \\
13.9 \\
13.9\end{array}$ \\
\hline & & AUERACT VAL & & \\
\hline 1 & $9 ? 6 \cdot 3$ & $654 . ?$ & 830.9 & 15.5 \\
\hline 2 & 2.2 .5 & 604.1 & $=04.6$ & 13.9 \\
\hline
\end{tabular}

(b) $1366 \mathrm{~K}$ tensile properties

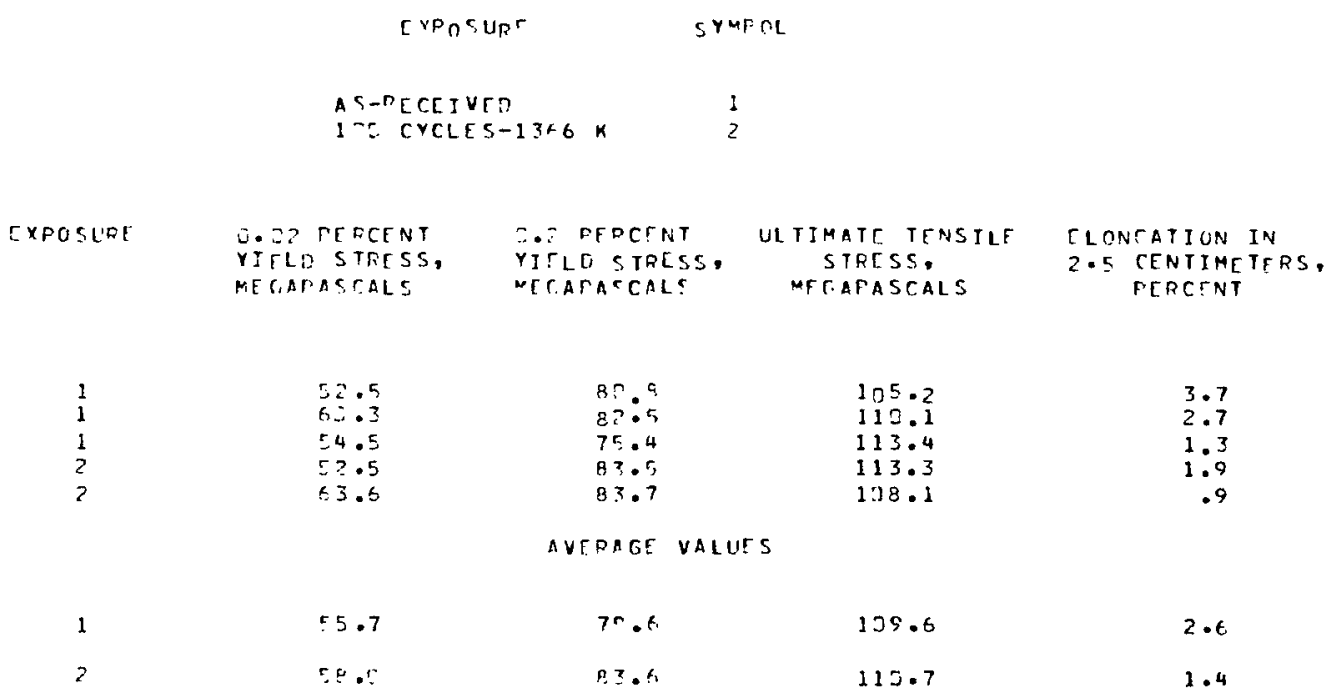


TABLE VII. - Continued.

(c) $1366 \mathrm{~K}$ creep strength properties

TXPOSUFE SYMROL

AS-RTCEIVED

105 CYCLES-1366 K

1

\begin{tabular}{|c|c|c|}
\hline EXPOSUPE & $\begin{array}{l}\text { ELAGTIC } \\
\text { STRAIN } \\
\text { ONLOAOING. } \\
\text { PERTENT }\end{array}$ & $\begin{array}{l}\text { PLASTIS } \\
\text { STOAIN } \\
\text { ON LOATING } \\
\text { DEOCFNT }\end{array}$ \\
\hline 1 &.-10 &.$<00$ \\
\hline 1 & .710 & $\cos$ \\
\hline 1 & .05 & .004 \\
\hline 1 & .80 & .018 \\
\hline 1 &.$r 10$ & .020 \\
\hline 1 &.$r 20$ & $.04]$ \\
\hline 2 & $.23 c$ & .012 \\
\hline 2 & .515 & \\
\hline 1 &.-30 & .070 \\
\hline 1 & $\cdot r 2 C$ & $.04=$ \\
\hline 1 & .93 & . 25 \\
\hline 2 & $.76 ?$ & .190 \\
\hline 2 &.$r 6 ?$ & .020 \\
\hline
\end{tabular}

TIME (HOURS) REOUIOED TO PRODUCE FOLLOUING STPAINS (PERCENT)

$$
\begin{array}{llll}
0.1 & 0.2 & 0.5 & 1.0
\end{array}
$$

CREEP STRAIN END OF TEST 1150 HOURSI.

TOTAL PLASTTC

CREEP STRAIN

END OF TEST

APPROXIMATE

PERCENT (15O HOURS), PERCEN T

STRESS $=13.8$ MEGAPASCALS

$9.1 \quad 134.2$

145.1

STRESS $=22.7$ MEGAPASCALS

54.3

$0.2 \quad 5.97$

C.1 9.8

196.5

STFESS $=27.6$, MEGAPASCALS

$\begin{array}{rr}20.6 & \\ 12.5 & 127.5 \\ 77.5 & \\ 1.9 & 0.5 \\ 4.1 & 16.2\end{array}$

$\begin{array}{lll}.26 & .26 & <.300-09 \\ .08 & .08 & .880-09 \\ .11 & .11 & .300-69\end{array}$

.14
.30
.33

.33

.14

.15
.32
.37
.15
.12

$<.300-[9$

$.300-09$
$300-09$

$.300-09$
$.850-60$

$.850-69$
$.300-5.9$

.17
.24
.14
.33
.33

$\begin{array}{ll}.24 & .130-08 \\ .28 & .150-08 \\ .19 & .190-08 \\ .54 & .130-08\end{array}$


TABLE VII. - Concluded.

(d) Room temperature residual tensile properties after creep testing at $1366 \mathrm{~K}$

$$
\begin{aligned}
& \text { PLASMA APC TUNNEL SYMPOL } \\
& \text { TXPOSUPE }
\end{aligned}
$$

AS RECEIVEF
1 COCYCLST-1365K

FXPOSUP:

STRTSS,
MEGAPASCALS

PrIOP CDEEP HISTORY
TIME, CRECP STRAIN, TOTAL PLASTIC PERCENT CRFEP SIRAIN.
PERCENT PERCENT CRFEP SIRAIN
PERCENT

O.2 PERCENT
YIFLO STRESS,
MECAPASCALS

TENSILE PROPERTIES ULIIMATE ELONGATION,

MLCAPASCALS

TEASILE STRESS,

PERCENT

\section{NOT CRFEP TESTED}

NOT CFEEP TESTED

NOT CREEP TESTED

\begin{tabular}{|c|c|c|}
\hline $\begin{array}{l}632.5 \\
680.7\end{array}$ & $\begin{array}{l}786.8 \\
851.6\end{array}$ & $\begin{array}{l}15.7 \\
13.9\end{array}$ \\
\hline 649.7 & $8 \epsilon_{1} \cdot 2$ & 16.7 \\
\hline 654.5 & 821.3 & 13.9 \\
\hline 684.2 & 894.3 & 13.9 \\
\hline 649.7 & 863.3 & $14 \cdot 8$ \\
\hline $6^{8} 8 \cdot 3$ & 873.2 & 15.7 \\
\hline 618.7 & 776.5 & 13.9 \\
\hline 574.6 & 627.6 & $a_{1.9}$ \\
\hline 564.3 & 717.9 & 6.5 \\
\hline 524.3 & 694.5 & 11.1 \\
\hline 619.6 & 787.6 & 8.3 \\
\hline 722.7 & 841.5 & $b_{6.5}$ \\
\hline $\begin{array}{l}575.3 \\
571.2\end{array}$ & $\begin{array}{l}768.9 \\
722.1\end{array}$ & $\begin{array}{l}13.50 \\
b_{6} \cdot 5\end{array}$ \\
\hline 582.2 & 733.8 & $1[.2$ \\
\hline 711.7 & 894.5 & $12 . r$ \\
\hline 731.6 & 812,5 & $\bar{c}_{2.8}$ \\
\hline
\end{tabular}

${ }^{a}$ Fracture at region where creep extensometer attached, local oxidation visible.

${ }^{b}$ Out of gage failure.

${ }^{c}$ Creep damaged. 
TABLE VIII. - MECHANICAL PROPERTIES OF AS-RECEIVED AND PLASMA ARC TUNNEL

EXPOSED DS-NiCr(II)

(a) Room temperature tensile properties

$\begin{array}{lc}\text { EXPOSURE } & \text { SYMPOL } \\ \text { AS-RECEIVEO } & 1 \\ \text { 1CO CYCLES-1366 K } & 2\end{array}$

\begin{tabular}{|c|c|c|c|c|}
\hline EXPOSUPE & $\begin{array}{l}\text { J.EZ PERCENT } \\
\text { YIELD STRESS, } \\
\text { MEGAPASCALS }\end{array}$ & $\begin{array}{l}\text { E.2 PERCENT } \\
\text { YIFLD STRESS, } \\
\text { MEGAPASCALS }\end{array}$ & $\begin{array}{l}\text { ULTIMATE TENSILF } \\
\text { STRESS } \\
\text { MEGAPASCALS }\end{array}$ & $\begin{array}{l}\text { ELONCATION IN } \\
2.5 \text { CENTINETFRS, } \\
\text { FERCENT }\end{array}$ \\
\hline $\begin{array}{l}1 \\
1 \\
1 \\
1 \\
2 \\
2\end{array}$ & $\begin{array}{r}77.2 \\
188.9 \\
151.9 \\
452.4 \\
339.9 \\
431.8\end{array}$ & $\begin{array}{l}303.9 \\
343.4 \\
333.3 \\
484.0 \\
459 . ? \\
490 . ?\end{array}$ & $\begin{array}{l}686.7 \\
671.4 \\
646.8 \\
633.6 \\
633.4 \\
711.5\end{array}$ & $\begin{array}{l}17.6 \\
15.7 \\
15.7 \\
19.5 \\
19.5 \\
13.5\end{array}$ \\
\hline \multicolumn{5}{|c|}{ AVERAGF VALUES } \\
\hline 1 & 217.6 & 356.1 & 667.2 & 17.4 \\
\hline 2 & $385 \cdot 3$ & 478.7 & 673.9 & 10.5 \\
\hline \multicolumn{5}{|c|}{ (b) $1366 \mathrm{~K}$ tensile properties } \\
\hline \multicolumn{5}{|c|}{ E XPOS URE } \\
\hline \multicolumn{5}{|c|}{ AS-REREIVED } \\
\hline EXPOSURE & $\begin{array}{l}\text { O.C? FEFCFNT } \\
\text { YIELO STRESS, } \\
\text { MEEAPASCALS }\end{array}$ & $\begin{array}{l}\text { C.2 PEPCENT } \\
\text { YICLD STRESS, } \\
\text { MEGAPACALS }\end{array}$ & $\begin{array}{l}\text { ULTIMATE TENSILE } \\
\text { STPESS, } \\
\text { MEGAPASCALS }\end{array}$ & $\begin{array}{l}\text { FLONCATION I: } \\
2 . \text { CONTIMETR, } \\
\text { FERCENT }\end{array}$ \\
\hline $\begin{array}{l}1 \\
1 \\
1 \\
2 \\
2\end{array}$ & $\begin{array}{l}79.3 \\
65.9 \\
77.9 \\
64.7 \\
36.2\end{array}$ & $\begin{array}{r}100.5 \\
80.8 \\
10 \% \cdot ? \\
94.7 \\
90.1\end{array}$ & $\begin{array}{l}115.5 \\
112.7 \\
112.2 \\
129.3 \\
110.3\end{array}$ & $\begin{array}{l}4.6 \\
6.5 \\
4.6 \\
1.9 \\
2.8\end{array}$ \\
\hline \multicolumn{5}{|c|}{ AVEFAGF VALUTS } \\
\hline 1 & 72.7 & 96.0 & 113.6 & 5.7 \\
\hline 2 & 2.5 & 92.4 & 129.8 & $\therefore . ?$ \\
\hline
\end{tabular}


TABLE VIII. - Continued.

(c) $1366 \mathrm{~K}$ creep strength properties

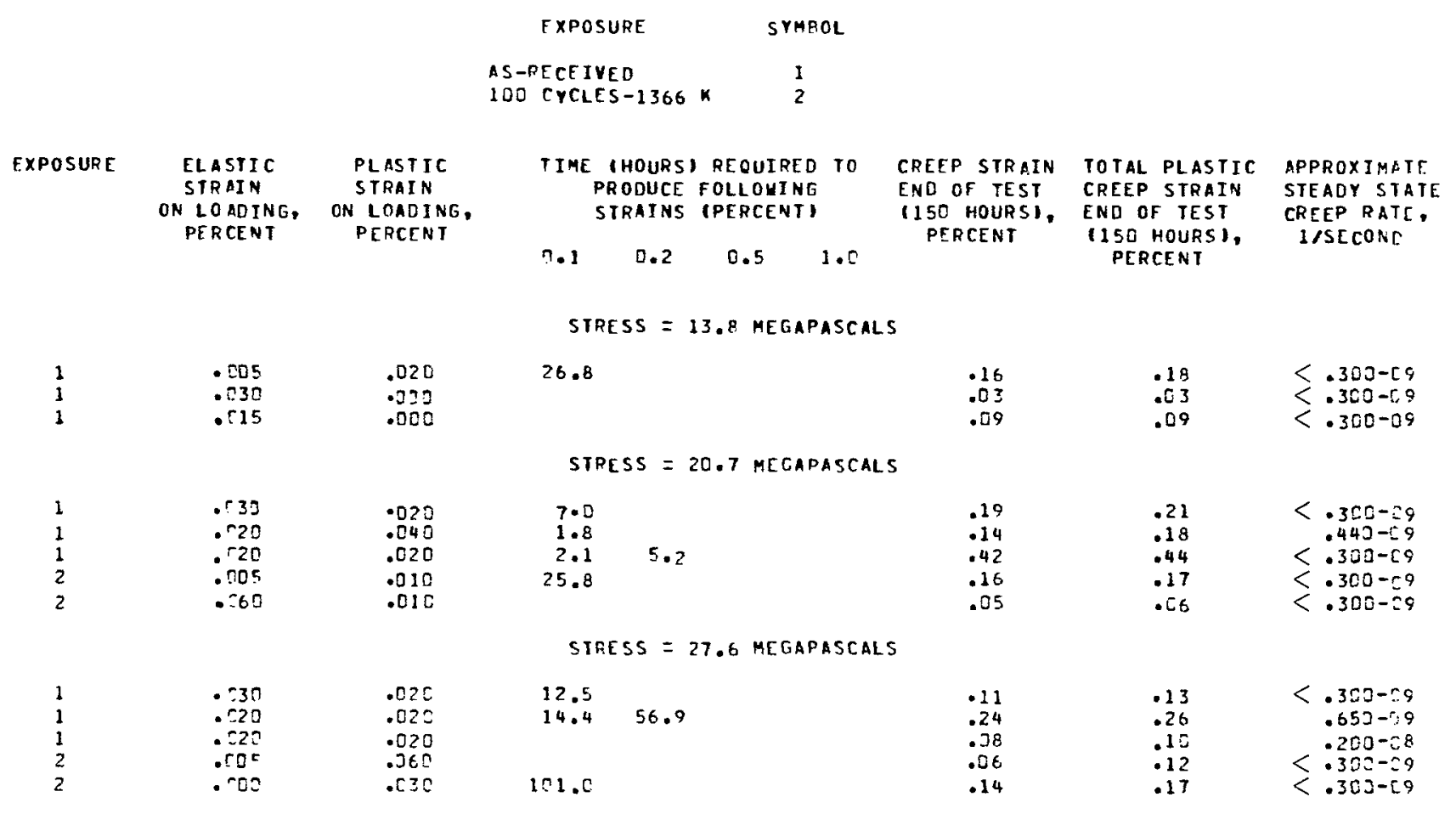


TABLE VIII. - Concluded.

(d) Room temperature residual tensile properties after creep testing at $1366 \mathrm{~K}$

PLASMA ARC TUNNEL
SXPOSURE
AS RECEIVED
100 CYCLTS-1366 K

EXPOSURE

$$
\text { STRESS, }
$$

PRIOR CREEP HISTORY

TIME, CREEP STRAIN, TOTAL PLASTIC

MEEAPASCALS

HOURS

PEOCENT

CREEP STRAIN,

NOT CREEP TESTED

NOT CREEP TESTED

NOT CPEEP TESTED

NOT CREEP TESIED

NOT CREEP TESTE

NOT CREEP TESTFO

1
1
1
1
1
2
2
1
1
2
2

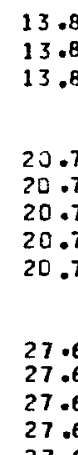

150.0
150

150.0

.16

.03
.09

.03

PEPCENT

0.2 PEPCENT

ESIOUAL TENSILE PROPEFTIES

MELAPASCALS

ULTIMATE.

TLONCATION,

MEGAPASCALS MEGAPASCALS

PERCENTT

$\begin{array}{lll}3 E 3.2 & 684.9 & 17.6 \\ 342.4 & 679.4 & 16.7 \\ 333.5 & 647.0 & 15.7 \\ 483.7 & 662.8 & 19.5 \\ 459.6 & 632.5 & 18.5 \\ 498.8 & 713.5 & 18.5\end{array}$

$150.0 \quad .19$

150.0

150.0

150.0

.19
.14
.42
.16

150.3

.05

517.4
483.7

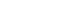

483.7
434.1

722.8

716.6

639.4

25.4
18.5

447.8

627.7

449.9

429.2

482.3
471.3

657.3
652.5

673.3

651.4

19.4

150.0
150.0

150.0

150.0

150.0

.11
.24
.08
.06

.17
.06

434.8
442.3

456.1

472.2

651.8
650.4
651.8

651.2

656.2
662.4

$1 \mathrm{c} \cdot 2$

16.7
18.5

13.9

13.5

a Out of gage failure. 
TABLE DX. - MECHANICAL PROPERTIES OF AS-RECEIVED AND PLASMA ARC TUNNEL EXPOSED TD-NiCrAl

(a) Room temperature tensile properties

$\begin{array}{lc}\text { CYPOSURE } & \text { SYMPOL } \\ \text { AS-RECETVER } & 1 \\ \text { IET CYCLES-14:7 K } & 2\end{array}$

\begin{tabular}{|c|c|c|c|c|}
\hline EXPOSURE & $\begin{array}{l}\text { J.CE PFPCENT } \\
\text { YITLD STRESS, } \\
\text { MEGAPASCALS }\end{array}$ & $\begin{array}{l}\text {.2 PEQCFNT } \\
\text { YITLD STRESS, } \\
\text { MECAPASCALS }\end{array}$ & $\begin{array}{l}\text { ULTIMATE TENSTLE } \\
\text { STRESS } \\
\text { MEGAPASCALS }\end{array}$ & $\begin{array}{l}\text { ELONCATION IN } \\
2.5 \text { CENTIMEIERS, } \\
\text { PERCENT }\end{array}$ \\
\hline $\begin{array}{l}1 \\
1 \\
2 \\
2\end{array}$ & $\begin{array}{l}492.8 \\
493.8 \\
212.6 \\
521.8\end{array}$ & $\begin{array}{l}614.1 \\
586.8 \\
523.8 \\
629.1\end{array}$ & $\begin{array}{l}867.6 \\
857 \cdot 5 \\
742.2 \\
925 \cdot 8\end{array}$ & $\begin{array}{r}8.0 \\
13.0 \\
12.0 \\
12.0\end{array}$ \\
\hline \multicolumn{5}{|c|}{ AVERAGE VALUFS } \\
\hline 1 & 487.9 & $6 \div 7.5$ & 862.6 & 10.5 \\
\hline 2 & 367.2 & 576.0 & 833.0 & 12.0 \\
\hline
\end{tabular}

(b) $1366 \mathrm{~K}$ tensile properties

EYPOSURT
SYMROL
AS-RECEIVED
1CO CYCLES-1477K K DXPCSUEE
YIELP PEPCENT ME GAPASCALS
$\because .2$ PEDCFNT ULTIMATE TEMSJL Merapascals STRESS. MEGAPASCALS
FLONGATION JN 2.5 CENTIMEILRS PERCENT

$\begin{array}{lrll}23.2 & 67.0 & 83.9 & 2.0 \\ 14.6 & 51.3 & 81.7 & 1.0 \\ 19.5 & 5 . .7 & 81.5 & 1.0 \\ 40.7 & 79.9 & 82.5 & 1.9 \\ 26.2 & 57.6 & 84.5 & .9 \\ & \text { AVERAGF VALUTS } & & \\ 19.1 & & & \\ 33.4 & 53.5 & 82.2 & 1.3 \\ & 58.7 & 88.5 & 1.4\end{array}$


TABLE IX. - Continued.

(c) $1366 \mathrm{~K}$ creep strength properties

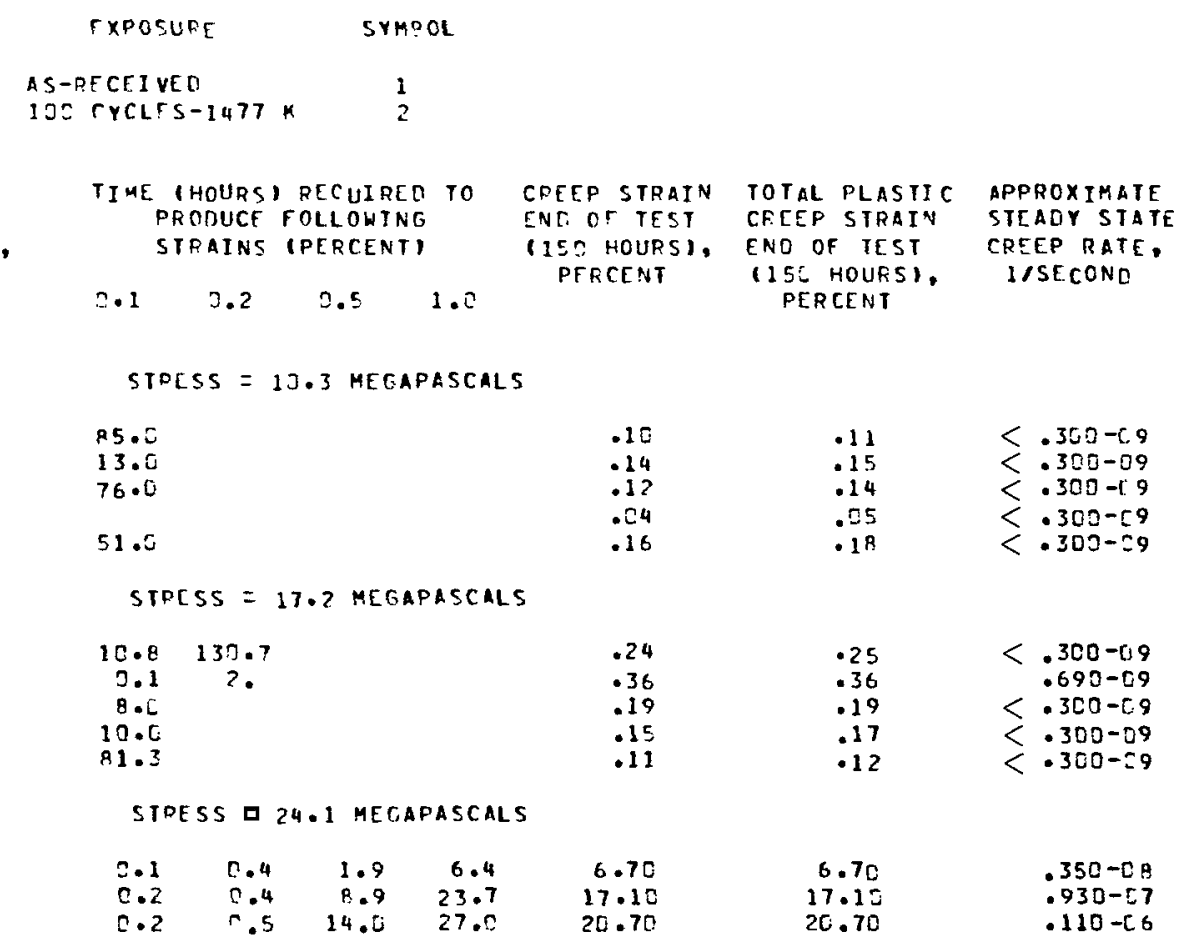


TABLE IX. - Concluded.

(d) Room temperature residual tensile properties after creep testing at $1366 \mathrm{~K}$

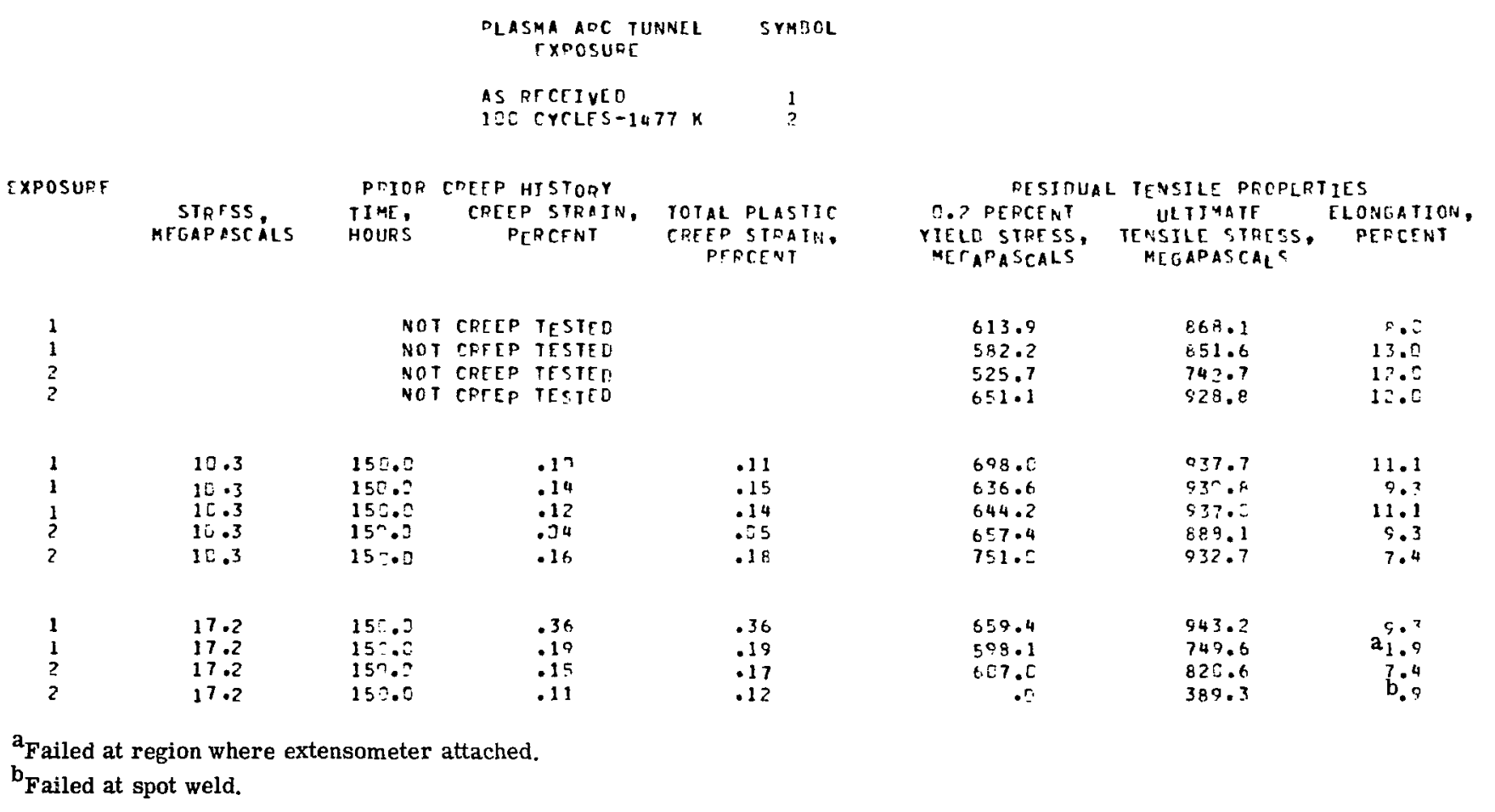


TABLE X. - MECHANICAL PROPERTIES OF AS-RECEIVED AND PLASMA ARC TUNNEL

\section{EXPOSED TD-NiCrAlY}

(a) Room temperature tensile properties

\begin{tabular}{|c|c|c|c|c|}
\hline \multirow[b]{3}{*}{ EXPOSURF } & \multicolumn{3}{|c|}{ EXPOSURE } & \\
\hline & \multicolumn{2}{|c|}{ AS-RECETVEO } & $\begin{array}{l}1 \\
?\end{array}$ & \\
\hline & $\begin{array}{l}\text { C.CZ PERCENT } \\
\text { YIELD STRESS, } \\
\text { ME GAPASCALS }\end{array}$ & $\begin{array}{l}\text { T.2 PEDCENT } \\
\text { YIFLO STOESS, } \\
\text { MEFAFACCALS }\end{array}$ & $\begin{array}{l}\text { ULTTMATF TENSTLE } \\
\text { STRESS, } \\
\text { MEGAFASCALS }\end{array}$ & $\begin{array}{l}\text { FLONTATION IN } \\
2.5 \text { CENTIMETTRS, } \\
\text { FERCENT }\end{array}$ \\
\hline $\begin{array}{l}1 \\
1 \\
1 \\
1 \\
1 \\
2 \\
2\end{array}$ & $\begin{array}{l}425.7 \\
424.7 \\
351.8 \\
310.5 \\
455.06 \\
191.8 \\
345.7\end{array}$ & $\begin{array}{l}557.7 \\
51 \% .7 \\
47 \% .7 \\
486.1 \\
554.6 \\
358.9 \\
529.0\end{array}$ & $\begin{array}{l}963.4 \\
889.7 \\
85.6 .6 \\
955.8 \\
950.9 \\
669.7 \\
603.8\end{array}$ & $\begin{array}{r}9.0 \\
9.0 \\
12.0 \\
10.0 \\
11.0 \\
11.1 \\
a_{5} .5\end{array}$ \\
\hline & & AVERAGF VAL & & \\
\hline 1 & 393.7 & $E 15.5$ & 972.7 & 9.8 \\
\hline 2 & 268.5 & $433 \cdot 9$ & 676.8 & a. 8 \\
\hline
\end{tabular}

$a_{\text {Failed at spot weld. }}$ 
TABLE X. - Continued.

(b) $1366 \mathrm{~K}$ tensile properties

E XPO SURT

SYMPOL

AS-RECEIVED
1 CC CRCLES-1477K

FXPOSURE

1
1
1
2
7

1

2

\section{G. 22 PERCENT YiLLD STRES ML GAPASCALS} O.2 PEPCTNT
YIELO STRESS,
MEGAPACALS

TIMATE TENSILE STRESS, MEGAMASCALS

CLONGATION IN $2 \cdot 5$ CENTIMETERS,

37.7
41.1
23.9
44.7
25.9

34.2
35.2

$6 t=2$

63.9

87.5
75.9

A. 8.5

83.6

92.5

113.3

AVERAGE VALUTS

8.4.?

91.7

8.?

$102 \cdot 9$
1.5

1.0

2.9

$1 \cdot 5$

1.8 
TABLE X. - Continued.

(c) $1366 \mathrm{~K}$ creep strength properties

$\begin{array}{lc}\text { CXOOSUDE } & \text { SYMPOL } \\ \text { AS-RFCEIVEO } & 1 \\ \text { IEZ CYCLSS-1477K } & 2\end{array}$

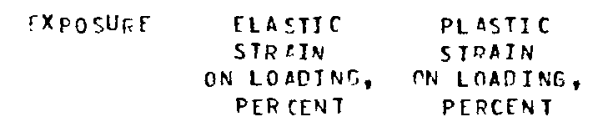

$\begin{array}{lll}1 & .040 & .012 \\ 1 & : 020 & .033 \\ 1 & : 20 & .033 \\ 2 & .035 & .060 \\ 2 & .02 & .030\end{array}$

$\begin{array}{lll}1 & .030 & .000 \\ 1 & : 30 & .055 \\ 1 & : 030 & .025 \\ 2 & : 50 & .000 \\ ? & .09 & .315\end{array}$

$\begin{array}{lll}1 & .520 & .095 \\ 1 & .050 & .040 \\ 1 & .060 & .375\end{array}$
TIME (HOURS) RFGUIPEO TO PRODUCF FOLLOKING
$n \cdot 1$
0.2

$$
0.5
$$$$
1.2
$$

CREFP STRAIN END OF TEST PIS HOURST, PERCENT

STOESS $=10 . ?$ MLTAPASCALS$$
190.0
$$

$6.7 \quad 57.2$

$6.1 \quad 14.5$

STRESS $=17.2$ MEGAPASCALS

$\begin{array}{rr}0.6 & 17.0 \\ 0.1 & 5.4 \\ 0.1 & 5.3 \\ 96.0 & \end{array}$

177.5

STPESS $=24.1$ MEGAPASCALS

$\begin{array}{lll}0.3 & 7.5 & \\ 0.1 & 5.2 & 100.3 \\ 0.3 & 1.0 & 156.0\end{array}$

.42
.33
.24
.11
.12

.34
.83

.83
.58
TOTAL PLASTIC APPROXIMATE CREEP STRAIV STEAOY STAT END OF TEST CREEP RATE I/SECOND

$\begin{array}{ll}.12 & .13 \\ .26 & : .29 \\ .03 & : .33 \\ .53 & : 33\end{array}$

$\begin{array}{ll}.12 & \\ .29 & \\ .190-C 8 \\ .300-09 \\ .33 & <300-69 \\ .33 & <.400-29 \\ .300-69\end{array}$

$\begin{array}{lr}.42 & .350-49 \\ .38 & .560-59 \\ .26 & <.300-[9 \\ .14 & .370-58 \\ .11 & <.300-[9\end{array}$

.43
.87
.65

$.24 C-C 8$
$570-58$

$.610-c 9$ 
TABLE X. - Concluded.

(d) Room temperature residual tensile properties after creep testing at $1366 \mathrm{~K}$

$$
\begin{aligned}
& \text { PLASMA APC TIINNEL SYMEOL } \\
& \text { EXPOSURE. } \\
& \text { AS RTCEIVER }
\end{aligned}
$$

\section{FXPOSUPE}

STRESS, MEGAPASCALS
PIIOR CRFEP HISTORY

TIME CREEP HTSTORY TIME, CREEP STRAIN, TOTAL PLASTIC
HOURS PRETS CREEP STPAIN. PERCENT

$$
\begin{aligned}
& \text { NOT CREEP TESTED } \\
& \text { NOT CRFEP TESTED } \\
& \text { NOT CRFEP TESTED } \\
& \text { NOT CREEP TESTFD } \\
& \text { NOT CREEP TESTED } \\
& \text { NOT CREEP TESTED } \\
& \text { NOT CREEP TESTFD }
\end{aligned}
$$

\section{3}

$10 \cdot 3$

10.3

10.3

$15^{-.2}$

150.0

$15 \mathrm{C} \cdot \mathrm{J}$

15.00

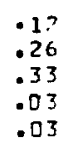

150.0

17.2

17.2

$15 \% .0$

155.3

24

24.1

24.2

150.0

150.0
$15 \% .2$
$15 \% .3$

${ }^{a_{\text {Failed at spot weld. }}}$
FESIMUAL TENSILE PRCPERTIES O.2 FEFCEA ULTIMATE ELONGATION, VITLO SIRESS, TENSILE STRESS PEPCENT

553.

511.9

473.3

485.7

554.6

363.3

FGAPASCALS

$\begin{array}{ll}861.2 & 9.6 \\ 892.3 & 9.5\end{array}$

858.5

$855.7 \quad 1 \mathrm{C} . \mathrm{C}$

$901.2 \quad 11.0$

$\begin{array}{ll}672.5 & 11.1 \\ 686.2 & \mathrm{a} 6.5\end{array}$

$6 \geq 3.9$

624.2

575.3

628.5

936.4

929.5

$90 \% 9$

915.6

$9 \cdot 3$

b3..

IC. 2

546.4
613.2

613.2

631.1
659.1

$96=.5$

914.3

860.9

15.2

7.4

7.3
4.8

550.5

430.6
527.1

649.7

$957 .=$

b. 9

.43
.87
.65

717.9

b $\begin{aligned} & 7.4 \\ & 1.9\end{aligned}$ 
TABLE XI. - MECHANICAL PROPERTIES OF AS-RECEIVED AND PLASMA ARC TUNNEL EXPOSED HAYNES ALLOY 188

(a) Room temperature tensile properties

\begin{tabular}{|c|c|}
\hline F YPOSURT & SYM \\
\hline $\begin{array}{l}\text { AS-RECCIVED } \\
1 \Gamma=\text { CYCESS-1255 } \\
\text { E- CYCLES-1?GE }\end{array}$ & $\begin{array}{l}1 \\
2 \\
3\end{array}$ \\
\hline
\end{tabular}

ExPOSURE

D.iz PEPCENT MECLPASCALS

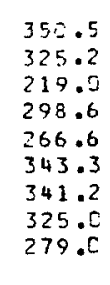

$292 \cdot 0$

342.2

302.0

\begin{abstract}
302 PERCFNT YITLD STRESS,
\end{abstract}

UL TIMATE TENSTLE STRESS,

ELONTATION IN 2.5 CENYIMEIEFS,

055.0

918.8

944.6
R 89.3

937.1

899.5

898.5

$773 \cdot 3$

446.7

396.0
398.9

AVERAGE VALUFS

467.7

442.5

397.5
928.0

899.5

773.5

$$
\begin{aligned}
& 47.0 \\
& 47.5 \\
& 46.0 \\
& 46.0 \\
& 50.0 \\
& 39.8 \\
& 40.7 \\
& 38.9 \\
& 47.2 \\
& 47.2 \\
& 40.2 \\
& 43.5
\end{aligned}
$$


TABLE XI. - Continued.

(b) $1255 \mathrm{~K}$ tensile properties

$\begin{array}{ll}\text { CXPOSURE } & \text { SYMPOL } \\ \text { AS-RECEIVED } & 1 \\ \text { 1CO CYCLES-1255 K } & 2 \\ \text { 5C CYCLES-1366 K } & 3\end{array}$

Exposuer

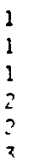

1

?

3
O. ? PEDCENT YIELO STRESS ME GAPASCALS 0.2 PERCENT
YIELD SIRESS MEGAPASCALS

\section{UL TI} TIMATE TEN
STRESS MEGAPASCAL

ELONGAT TON IN

2.5 CENTIMETERS, PERCENT

95.6
106.6
98.3
130.5
107.7

107.7

95.0

averagr values

$\begin{array}{ll}100.2 & 18.4 .6 \\ 110.1 & 189.9 \\ 95 .- & 16.3 .9\end{array}$

16.3 .9
21.8

23.0

23.5

24.9

16.7

$\begin{array}{ll}187.4 & 24.0 \\ 192.4 & 25.9 \\ 163.8 & 16.7\end{array}$

47.6
$7 \times .8$
$\times 5.4$

47.6

5.4

21.6

25.0

16.7 
TABLE XI. - Continued.

(c) $1255 \mathrm{~K}$ creep strength properties

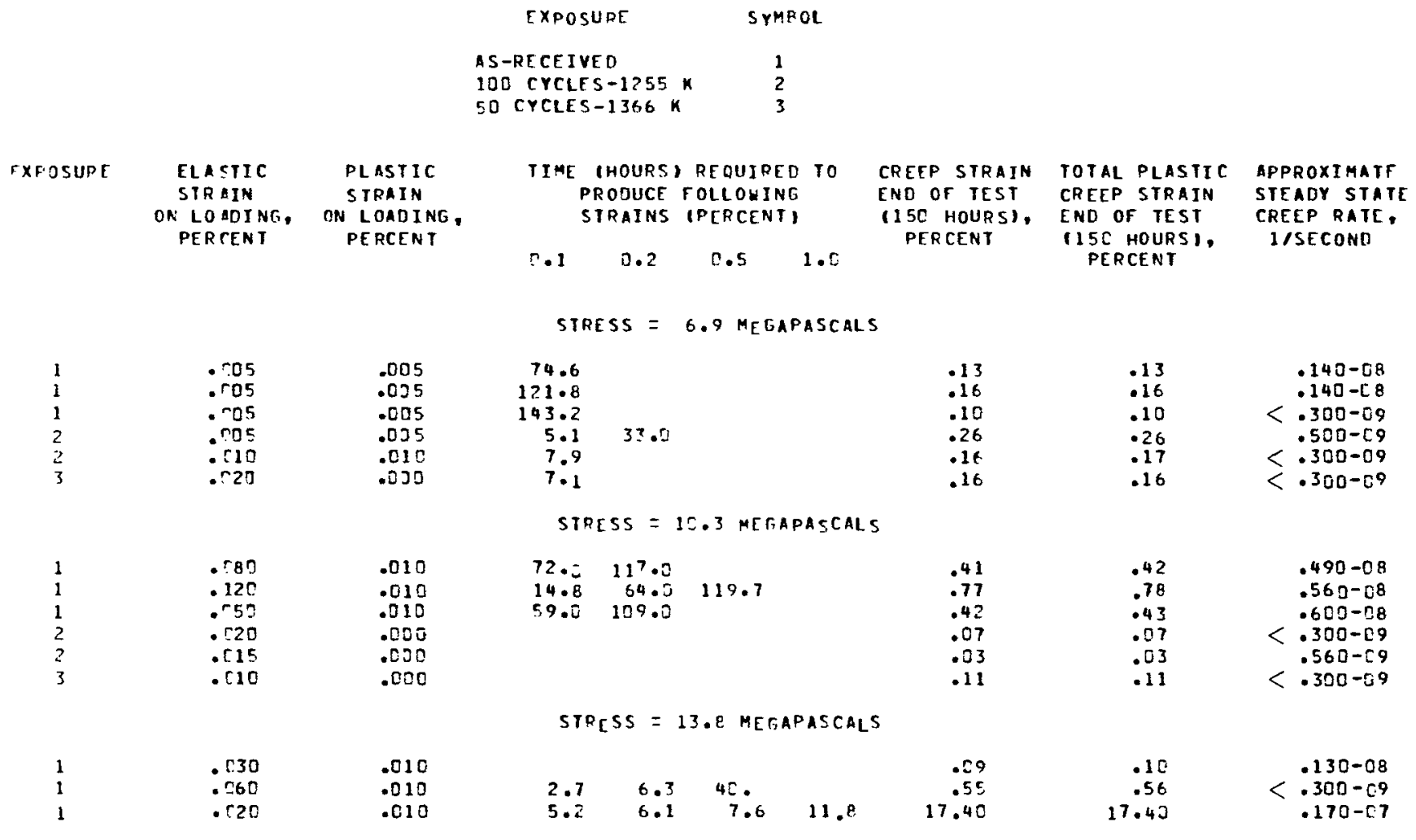


TABLE XI. - Concluded.

(d) Room temperature residual tensile properties after creep testing at $1255 \mathrm{~K}$

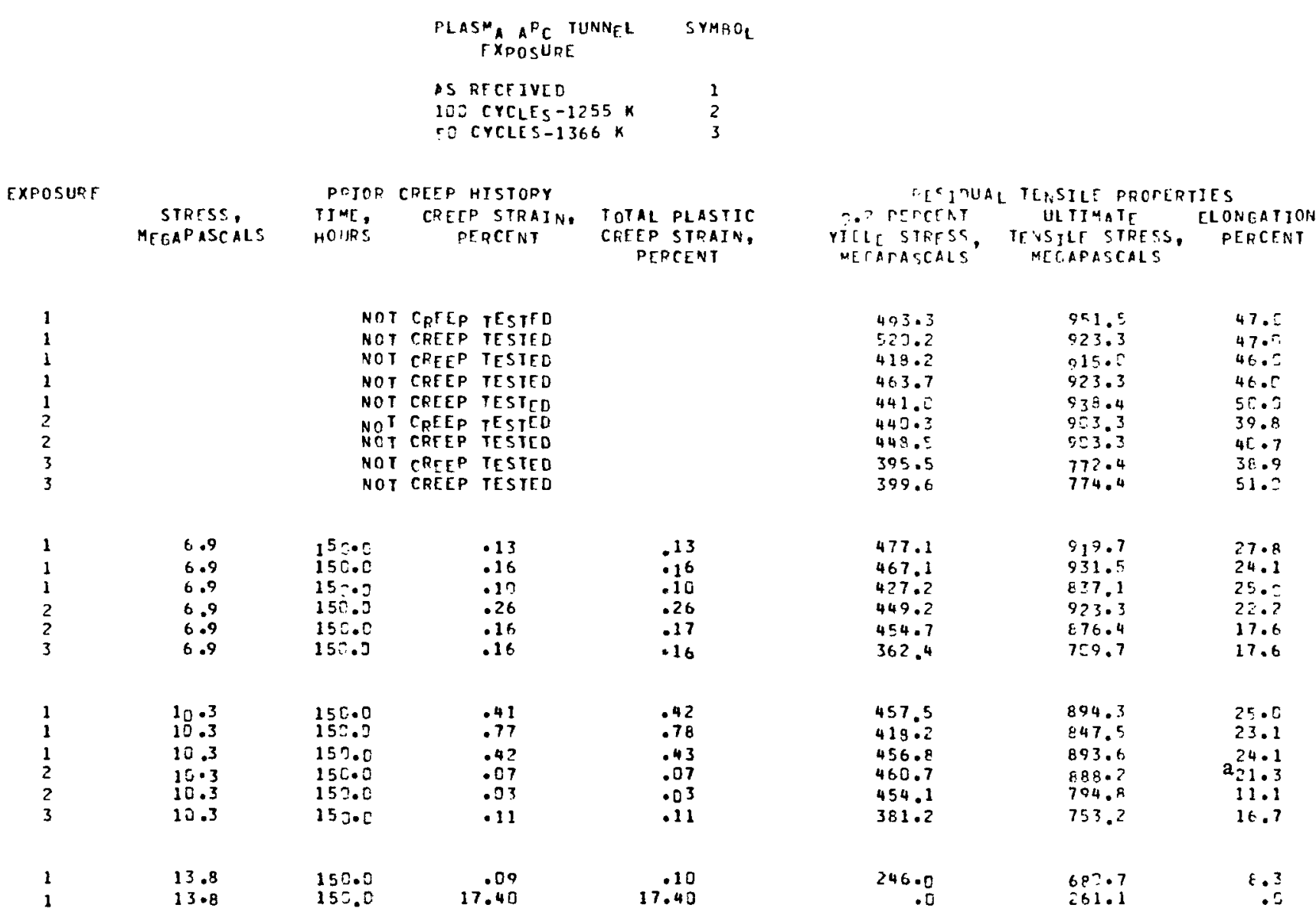

a Out of gage failure. 
TABLE XII. - MECHANICAL PROPERTIES OF AS-RECEIVED AND PLASMA ARC TUNNEL

EXPOSED HASTELLOY X

(a) Room temperature tensile properties

$\begin{array}{lc}\text { FXPOSURE } & \text { SYMROL } \\ \text { AS-RECEIVED } & 1 \\ 1 Z E \text { CYCLES-1255 K } & 2\end{array}$

ExPOSURE

$$
\begin{aligned}
& \text { OCI PERCFNT } \\
& \text { YIELD STRESS, } \\
& \text { MECAPASCALS }
\end{aligned}
$$

YIELO STRESS YIELD STRESS,

$141 . t$

$$
\begin{array}{r}
193.6 \\
152.4 \\
25.01 \\
119.0 \\
182.9 \\
177.5 \\
0.6 .9
\end{array}
$$

178.7

\section{9}

$$
32=0
$$$$
32=.3
$$$$
288.1
$$$$
\text { ?04? }
$$$$
\text { AVEFACE VALUES }
$$

1

$$
315.4
$$
ULTJMATE TENSTLE
STRESS. MFGAPASCALS

766.1

775.8

708.6

733.4

680.9

680.9
680.9

CLONRATION IN . E CENTIMETI.RS, PERCENT

47.3

49.2

34.3

38.9

32.4

38.8

769.4

43.7

76.1 
TABLE XII. - Continued.

(b) $1255 \mathrm{~K}$ tensile properties

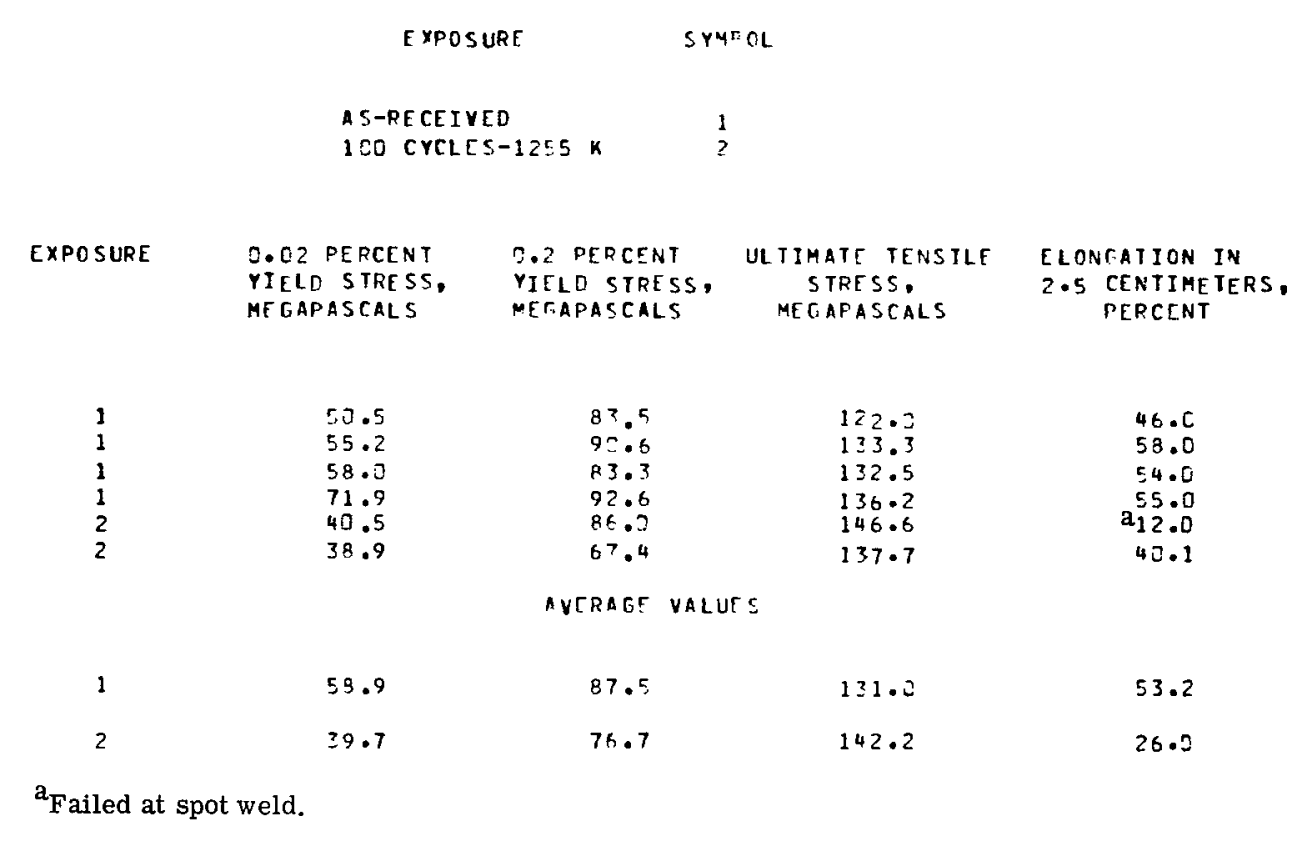


TABLE XII. - Continued.

(c) $1255 \mathrm{~K}$ creep strength properties

\begin{tabular}{|c|c|}
\hline TXPOSUPE & SYMFOL \\
\hline $\begin{array}{l}\text { AS-RTCEIVEO } \\
\text { 10C CYCLES-1755 }\end{array}$ & $\frac{1}{2}$ \\
\hline
\end{tabular}

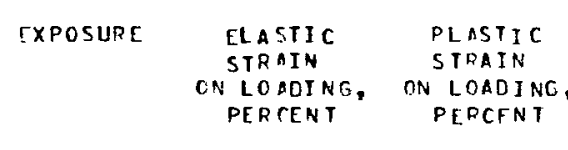

NLOAOING, ON LOADINC
PERTENT
TIME (HOURSI REQUIRED TO PROQUTC FOLLOWINC
STRAINS (PFRCENT)$$
0 \cdot 1
$$

$0.20 .5 \quad$ I.5
STRESS $=12.3$ MEgAPASCALS

CREEF STRAIN FVD OF TEST
IISO HOURST.

PERCENT

TOTAL PLASIIC APPROXIMATE

IISC HOUFS,

1 SC HOUFS
PERCENT

STEADY STATE

CREEP RATE,

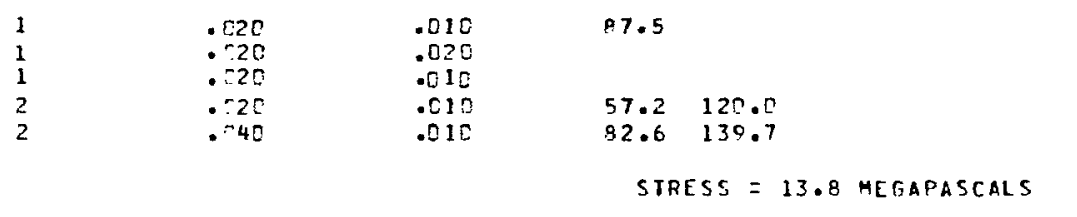

$\begin{array}{llr}.14 & .15 & .210-08 \\ .00 & .11 & .300-09 \\ .02 & .04 & .760-69 \\ .24 & .25 & .280-08 \\ .20 & .21 & .290-08\end{array}$

$\begin{array}{lll}1 & .020 & .060 \\ 1 & .025 & .050 \\ 1 & .020 & .050 \\ 2 & .025 & .045 \\ 2 & .032 & .030 \\ & & \\ 1 & .005 & .010 \\ 1 & .010 & .020 \\ 1 & .005 & .015\end{array}$

$\begin{array}{rr}73.5 & 139.6 \\ 51.7 & 84.3 \\ 15.5 & 144.7 \\ \text { STPESS }= & 17 .\end{array}$

.CE $\quad .06 \quad 0.300-09$

$.08<.13<.300-09$

$.220 .27 \quad .110-58$

$\begin{array}{lll}.26 & .31 & .350-28 \\ & .26 & .150-58\end{array}$

STPESS $=17.2$ MEGAPASCALS

66.5
7.8
59.0

.17
.47

$\begin{array}{ll}.18 & .13 C-C 8 \\ .49 & .303-58\end{array}$

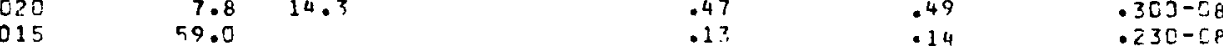


TABLE XII. - Concluded.

(d) Room temperature residual tensile properties after creep testing at $1255 \mathrm{~K}$

$$
\begin{aligned}
& \text { OLASMA ADC TIINNEL SYMEOL } \\
& \text { rXPusLor }
\end{aligned}
$$

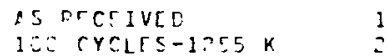

EXPOSURE

SIRESE
MECAFASCALS

PDIOR CRTLP HTSTCRY

Time, CREEP STKAIA,

HDUIR

TERCRT

TOTAL DLASTIS CPEEP STIAIN, PFRCENT

\section{NOT CFELP TESTED \\ NOT CELEP TESIEG \\ NOI CFrEP TESTEO \\ Not caref testro}

1
1
1
2
2

$12 \cdot 3$
10.3

10.3

1 $12 \cdot 3$

15.5
1502.0
150

$15=03$

$15=0$

.14
.20
.27
.24
.27

.15
.11
.24
.25
.21

$15=0$
$15 \div 0$
$15=0$

13.8

13.8

13.8
13.8
13.8

157.0

$15 \%$

.02
.30
.22
.23

153.0
150.0

17.2
17.2

159.

17.2

${ }^{a}$ Out of gage failure.
DESINUAL TENSILE PPOPERTIES

\begin{tabular}{|c|c|c|}
\hline 313.5 & 777.2 & $47 . ?$ \\
\hline 308.7 & 773.7 & $49 . ?$ \\
\hline 325.9 & 771.7 & 50.0 \\
\hline 272.8 & 695.9 & 34.3 \\
\hline 285.9 & 731.7 & 38.9 \\
\hline 321.8 & 751.7 & {$[1.3$} \\
\hline $3=2.5$ & 748.2 & 21.3 \\
\hline 311.4 & 747.6 & 23.1 \\
\hline 382.7 & 736.1 & 22.2 \\
\hline 293.5 & $67 \mathrm{C} .9$ & 14.8 \\
\hline $\begin{array}{l}328.5 \\
323.4\end{array}$ & $\begin{array}{l}777.9 \\
759.3\end{array}$ & $\begin{array}{l}25.0 \\
28.7\end{array}$ \\
\hline 290.1 & 772.4 & 20.4 \\
\hline 447.8 & 734.5 & 19.4 \\
\hline 320.4 & 564.3 & 7.4 \\
\hline 299.0 & $76=.7$ & $2 c .4$ \\
\hline 334.2 & 777.9 & $a_{19.4}$ \\
\hline 345.2 & $8[2]$. & 20. \\
\hline
\end{tabular}

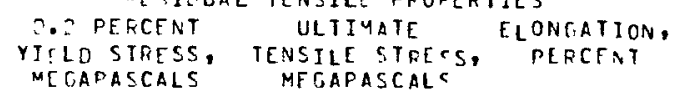


TABLE XUI. - MECHANICAL PROPERTIES OF AS-RECEIVED AND PLASMA ARC TUNNEL

EXPOSED DS-NiCr(I)

(a) Room temperature tensile properties

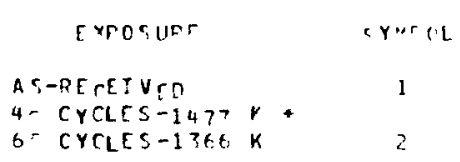

EXPOSURE

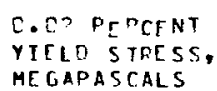

\section{7}

fIR - 1

$65 \% .5$

$85 \div .5$

55300

$798 \cdot 6$
849.5

$4+2$

15301

789.3

AVERAET VALUTS

654.9

$54 ? .5$

47,0

779.4

\section{7}

13.9

13.9

13.9
12.2
13.0

2

$54 ?$


TABLE XIII. - Continued,

(b) $1366 \mathrm{~K}$ tensile properties

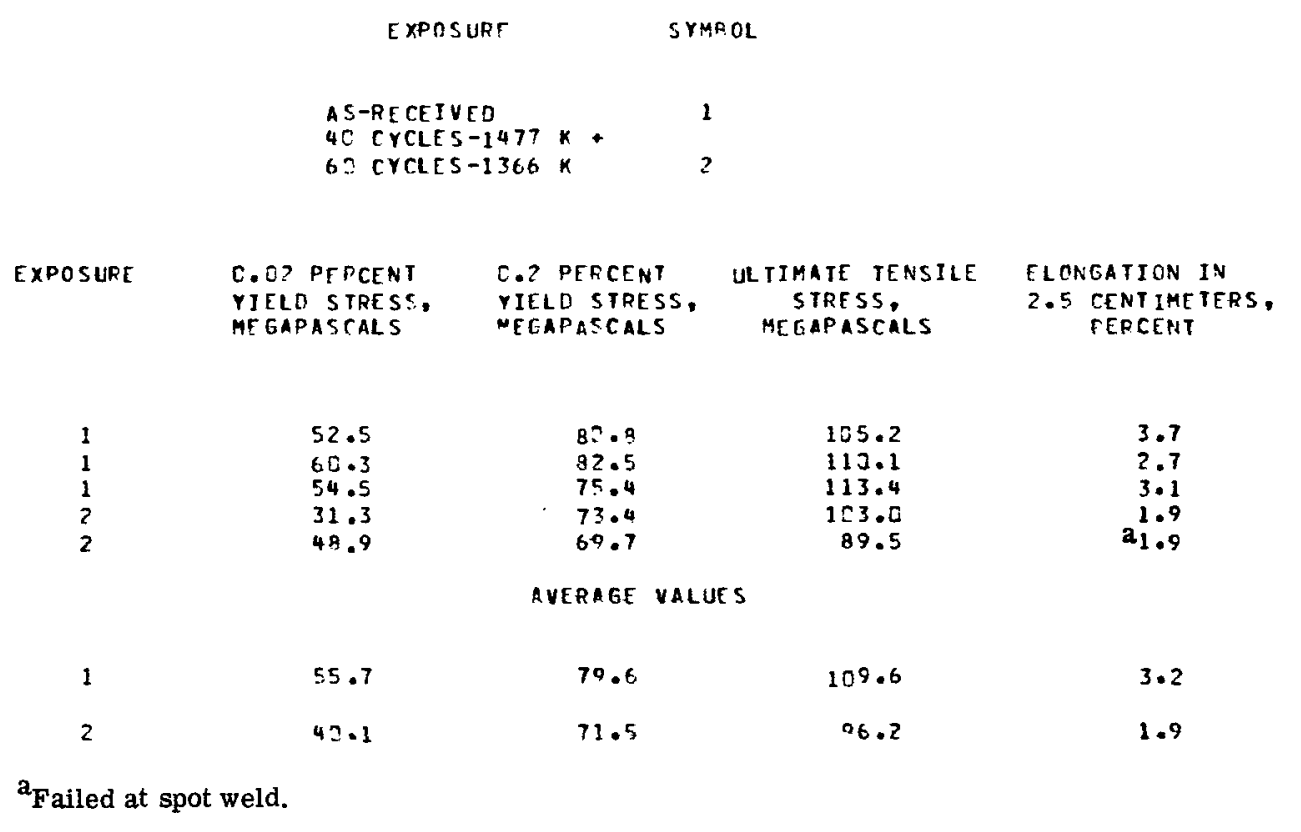


TABLE XIII. - Continued.

(c) $1366 \mathrm{~K}$ creep strength properties

CXOCEUET
AS-RECEIVEC SYMDOL
40 CYCLES-1477 K +
G CYCLES-1366 K

$\begin{array}{ccc}\text { EXPOSUPE } & \text { ELATTIC } & \text { PLASTIC } \\ \text { STRAIN } & \text { STRAIN } \\ \text { CN LOADING, ON LOADING } \\ \text { PERTENT }\end{array}$

TIME (HOURSI PFCUIRED TO
PRODUCF FOLLOWING. PRODUCE FOLLOWING
STPAINS (PEPCENTI

CPECP STRAIN END OF TEST (15T HOURSI,

TOTAL PLASIIC CREEP STFAIN PERTENT FERCTNT

n.1

$0.2 \quad 3.5 \quad 1.5$

PCACENT

CND OF TEST

STEAOY STAT CREEP RATE,

STRESS $=13.8$ METAPASCALS

$\begin{array}{lll}1 & .010 & .000 \\ 1 & .010 & .030 \\ 1 & .005 & \\ & & \\ & & \\ 1 & .004 \\ 1 & .060 & .010 \\ 1 & .020 & .020 \\ 2 & .015 & .042 \\ 2 & .025 & .025 \\ & & .025 \\ & & \\ 1 & .030 & .070 \\ 1 & .020 & .040 \\ 1 & .030 & .050 \\ 2 & .012 & .020 \\ 2 & .00 & .070\end{array}$

$\begin{array}{cc}9.1 & 134.2 \\ 145.1 & \\ \text { STRESS }= \\ 64.3 \\ 0.2 & 55.5 \\ 0.1 & 9.8 \\ 33.2 & \\ 116.5 & \\ \text { STRE } 55= \\ 20.6 \\ 12.0 \quad 127.0 \\ 77.5 & \\ 4.7 & 11 .\end{array}$

$\begin{array}{rrr}.26 & .26 & <.300-59 \\ .08 & .08 & .880-6.9\end{array}$

$.11<.08<.300-69$

$\begin{array}{rrr}64.3 & \\ .020 & 0.2 & 55.0\end{array}$

$0.1 \quad 9.8$

25

.070

.040
.050

.020
.076

$\begin{array}{rr}12.0 & 127.0 \\ 77.5 & 11.7\end{array}$

.14
.32
.33
.16
.18

.17
.24
.14
.42
.09

$\begin{array}{rr}.15 & <.300-59 \\ .32 & <300-69 \\ .37 & <.300-09 \\ .16 & .190-68 \\ .21 & .130-08\end{array}$

DL HOUPS)
PERCENT 
TABLE XIII. - Concluded.

(d) Room temperature residual tensile properties after creep testing at $1366 \mathrm{~K}$

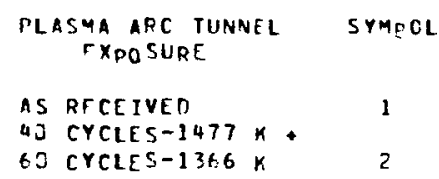

FXPOSURE STRESS
MEGAFASCALS POIOR CRECP HISTORY TIME, CREEP STRAIN HOURS PERCENT
PECE STRAT TOTAL PLASTIC PERCENT
PITAT

$$
\begin{array}{lll}
\text { NOT CREEP TESTED } \\
\text { NOT CREEP TESTID } \\
\text { NOT CREEP TESTED } \\
\text { NOT CREEP TESTED } \\
\text { NOT CRECP TESTED } \\
\text { NOT CRTEP TESTEO }
\end{array}
$$

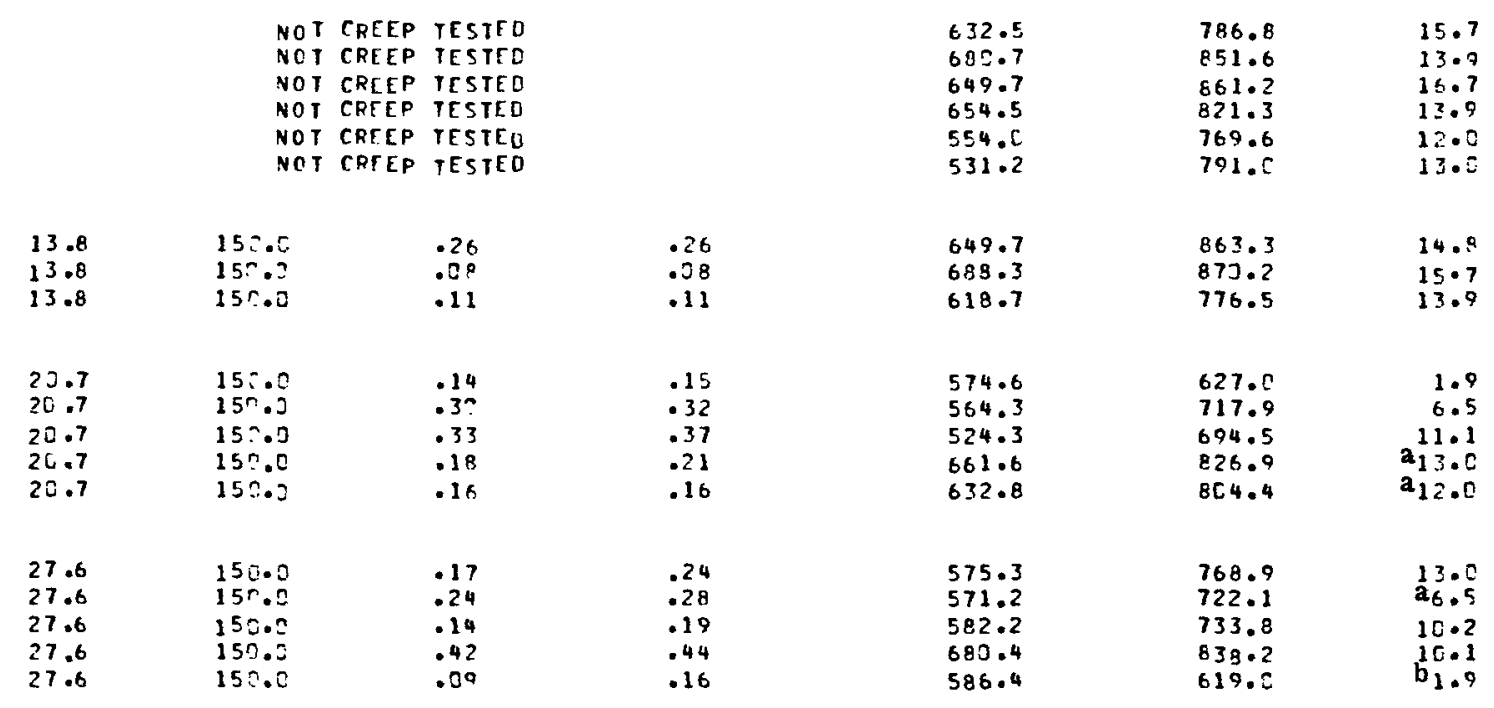

\section{RE SINUAL TENSILE PROPERTIES 0.2 PERCENT ULIMATE ELONGATION, YIELO STRESS, TENSILE STRESS METIAPASCALS MEEAPASCALS}

a Out of gage failure.

$b_{\text {Failed at spot weld. }}$ 


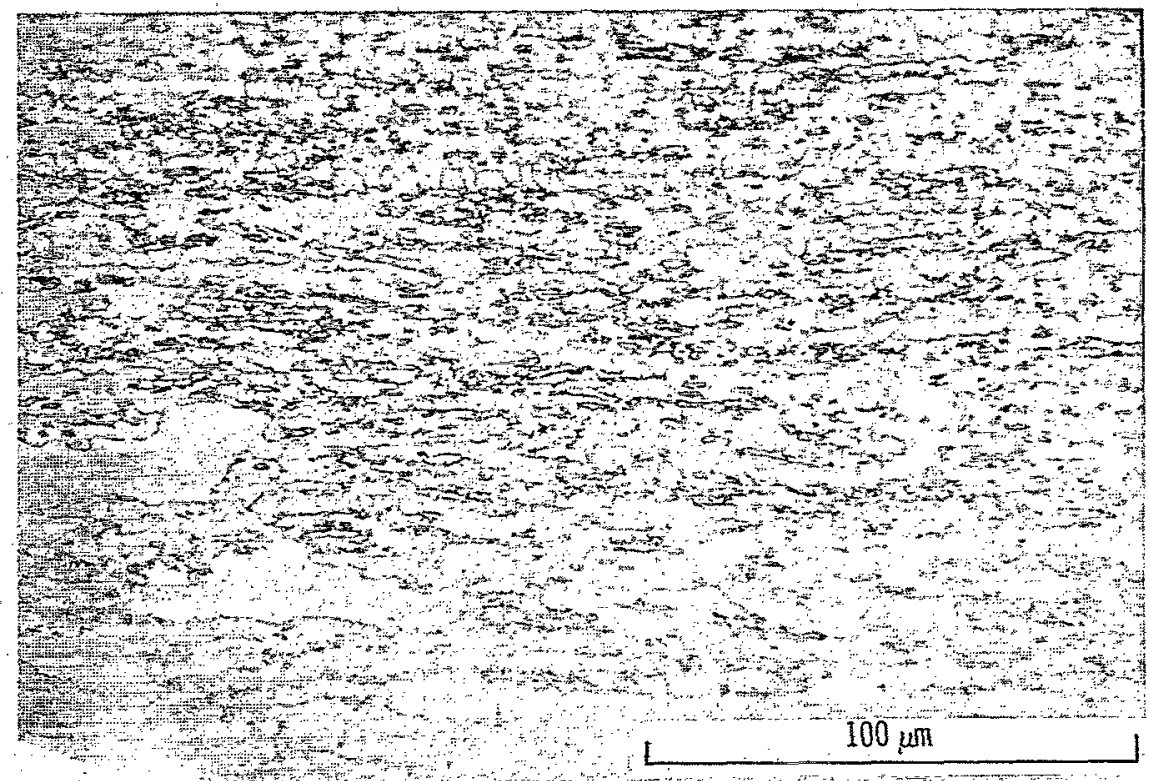

(a) DS-NiCr(I).

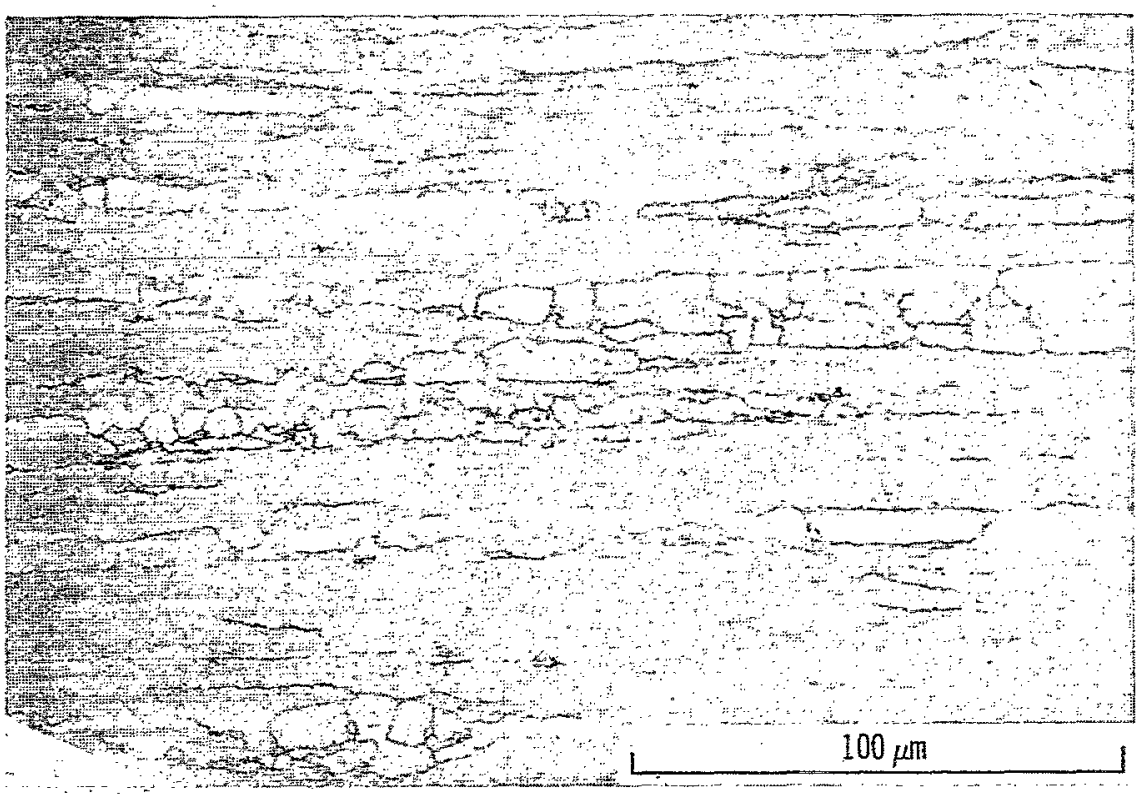

(b) DS-NiCr(II).

Figure 1. - As-received microstructures of $\mathrm{Ni}-2 \mathrm{OCr}-2 \mathrm{ThO}_{2}$ alloys produced by pack chromizing. Electrolytically etched in chromic acid mixture $\left(90 \mathrm{ml} \mathrm{H} \mathrm{H}_{2} \mathrm{O}-10 \mathrm{ml}\right.$ $\mathrm{H}_{2} \mathrm{SO}_{4}-2 \mathrm{~g}$ chromic acid). Microstructure consists of thoria-free (white) and thoria-containing (gray) bands. 


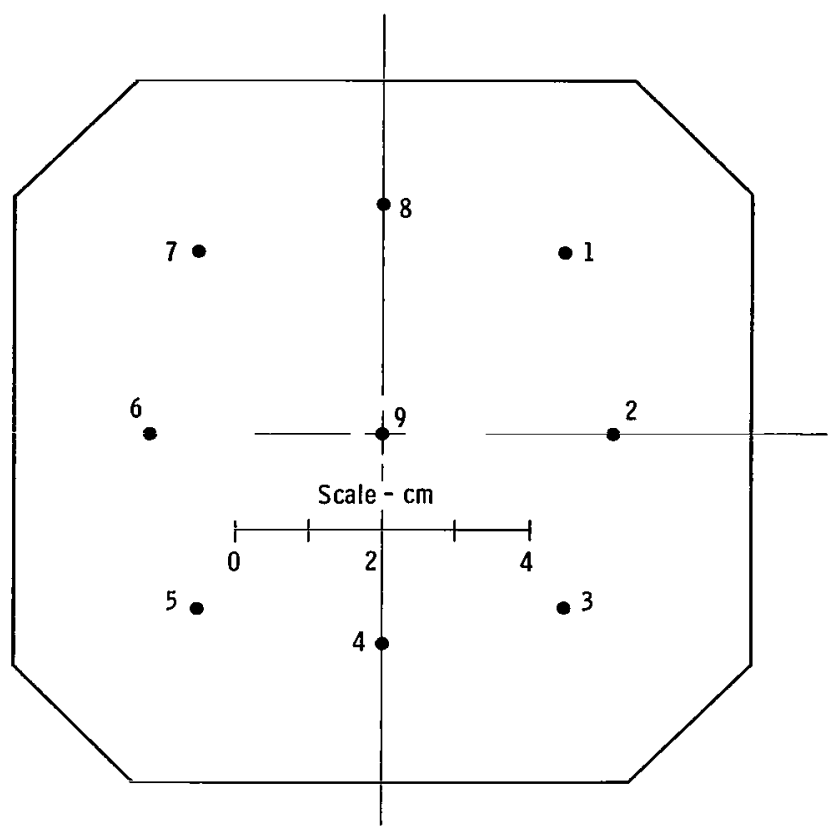

Figure 2 - Front view of Plasma Arc Tunnel test sample illustrating approxi mate thickness measurement locations (positions 1 to 9 ) and tack welded ther mocouple sites (positions 1, 3, 5, 7, and 9).

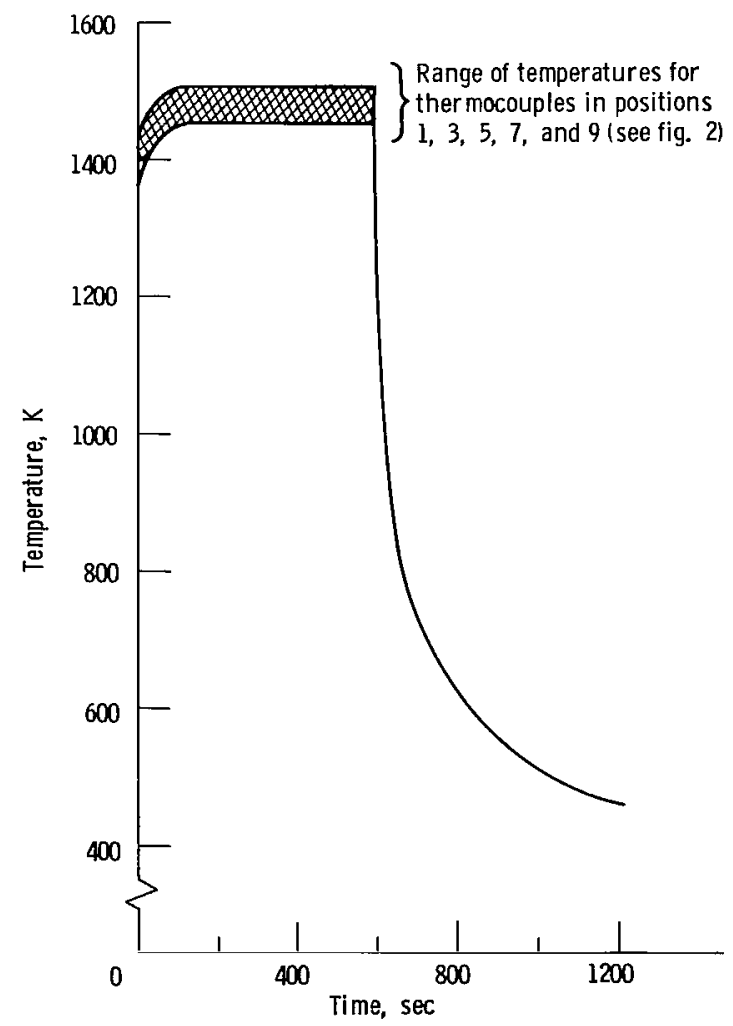

Figure 3. - Typical temperature history for TD-NiCrAl sample (ref. 10). 


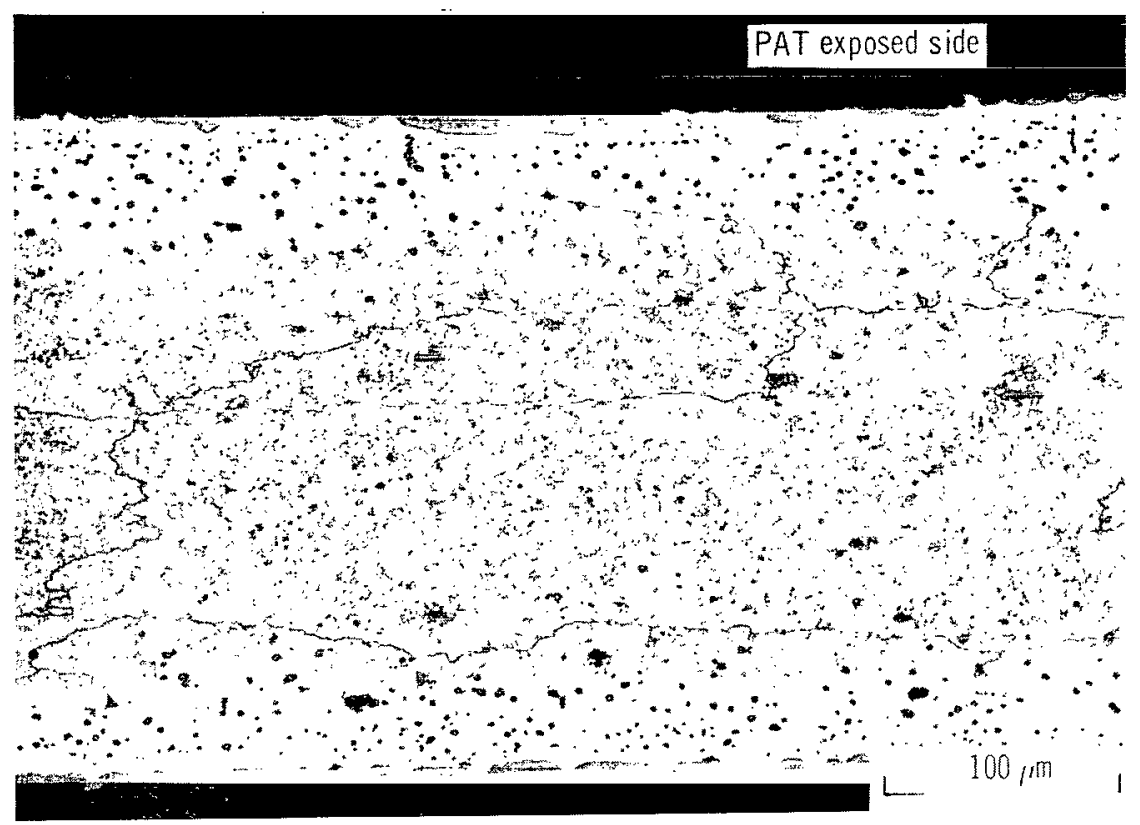

(a) TD-NiCr exposed for 100 cycles at $1366 \mathrm{~K}$. Electrolytically etched with chromic acid mixture.
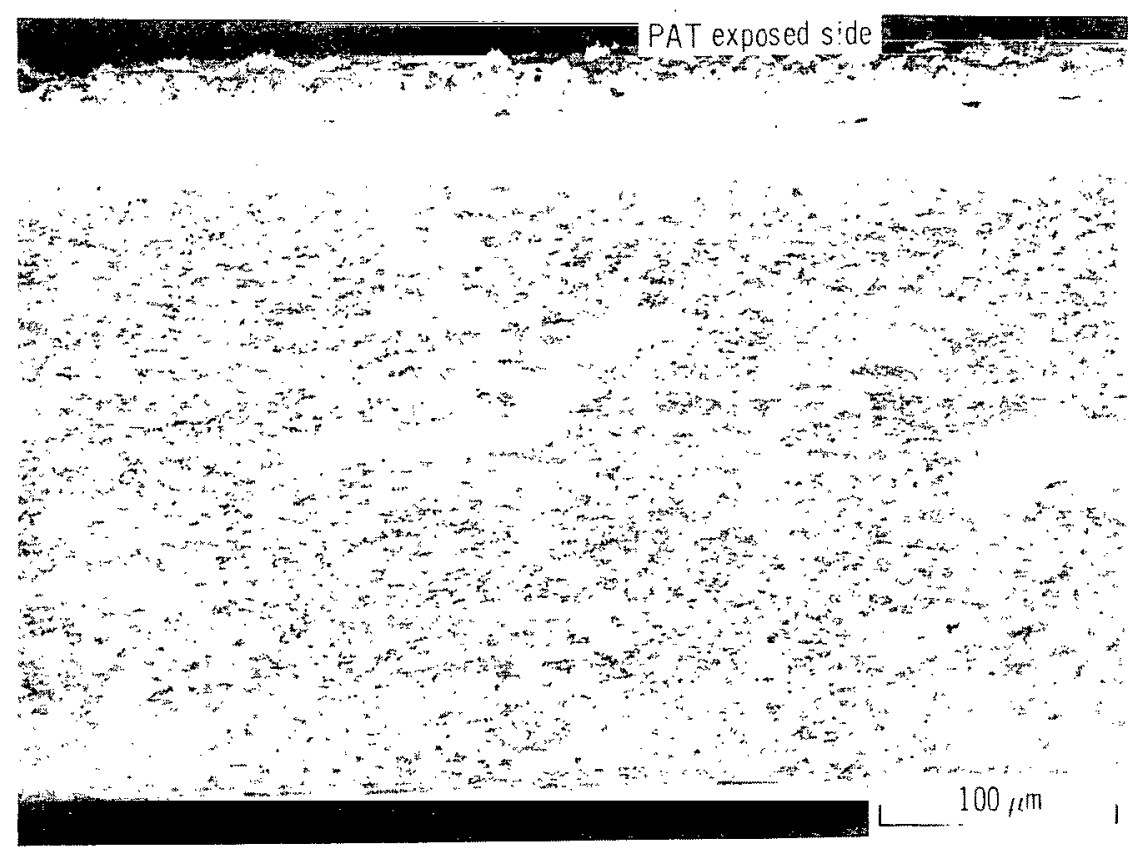

(b) DS-NiCr(I) exposed for 100 cycles at $1366 \mathrm{~K}$. Electrolytically etched with chromic acid mixture.

Figure 4. - Typical photomicrographs of Plasma Arc Tunnel exposed alloys. 


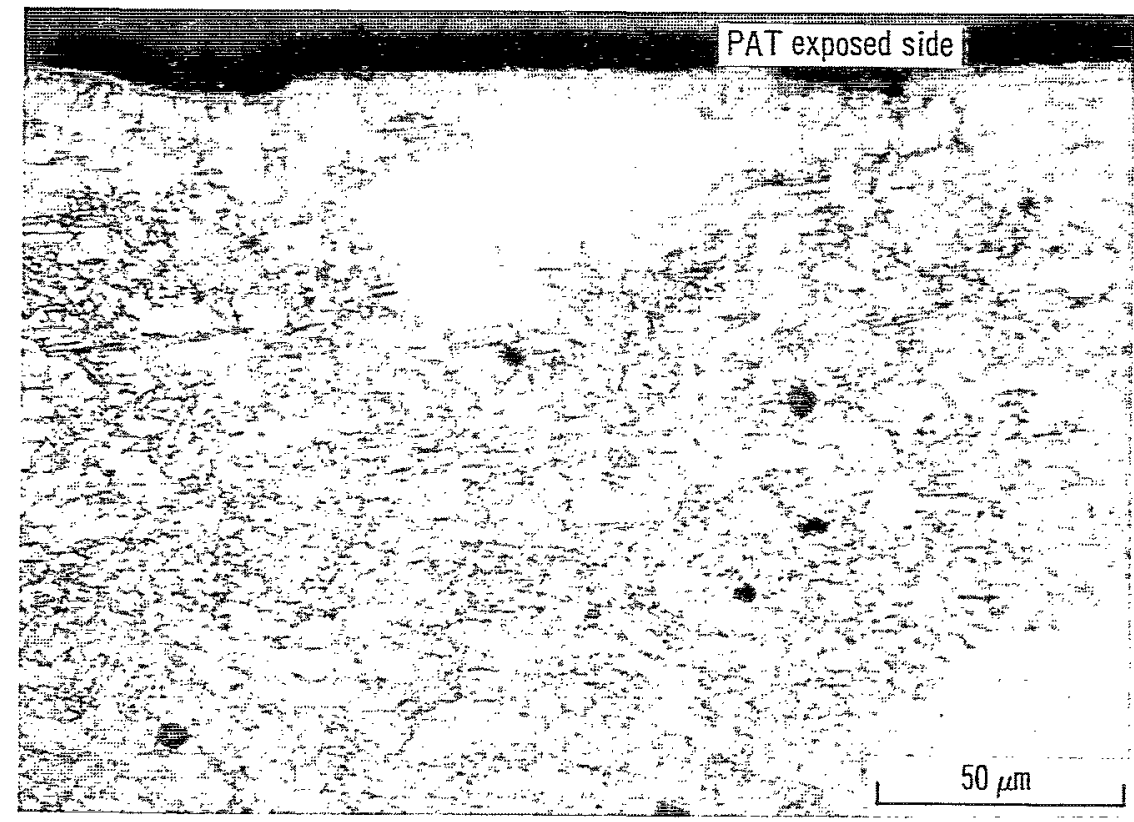

(c) TD-NiCrAl exposed for 100 cycles at $1477 \mathrm{~K}$. Electrolytically etched with chromic acid mixture.
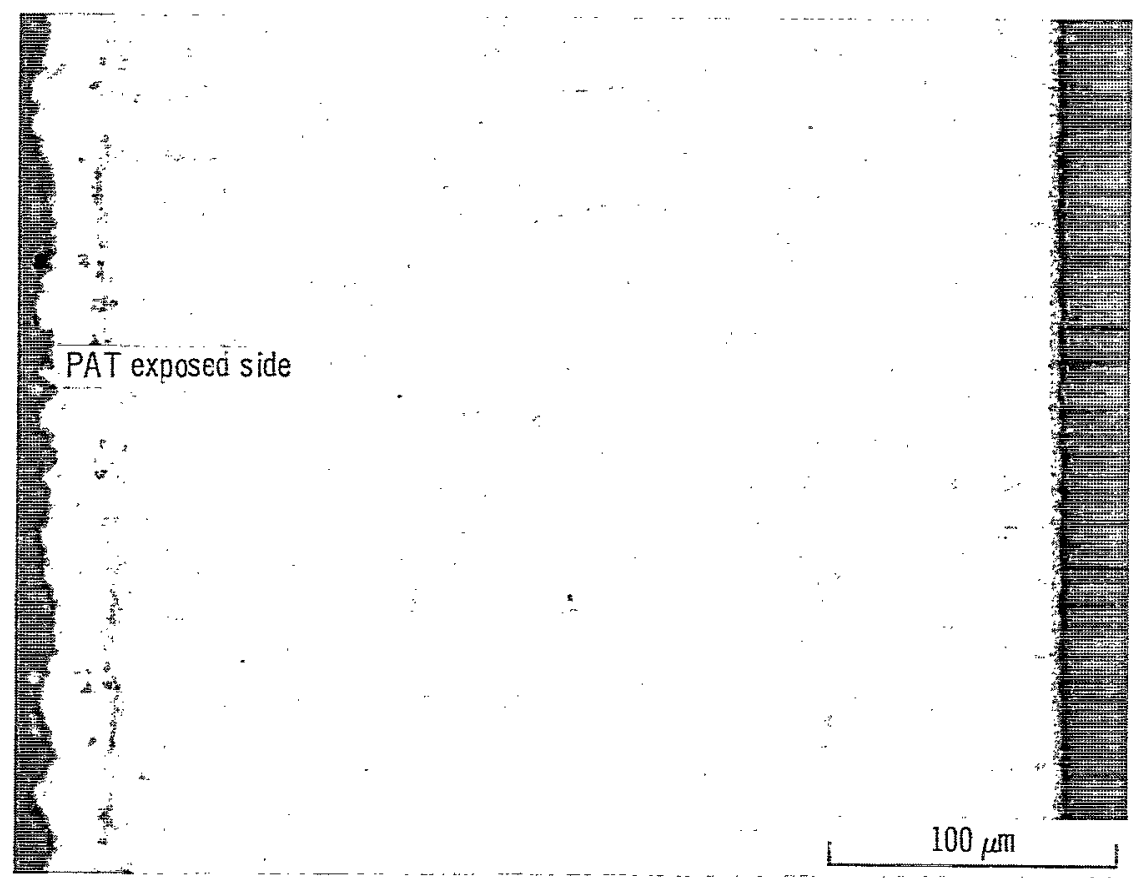

(d) Hastelloy exposed for 100 cycles at $1255 \mathrm{~K}$. Swab etched with mixed acids ( 33 parts by volume $\mathrm{H}_{2} \mathrm{O}, 33$ parts $\mathrm{HNO}_{3}, 33$ parts acetic acid, and 1 part HF).

Figure 4. - Concluded. 


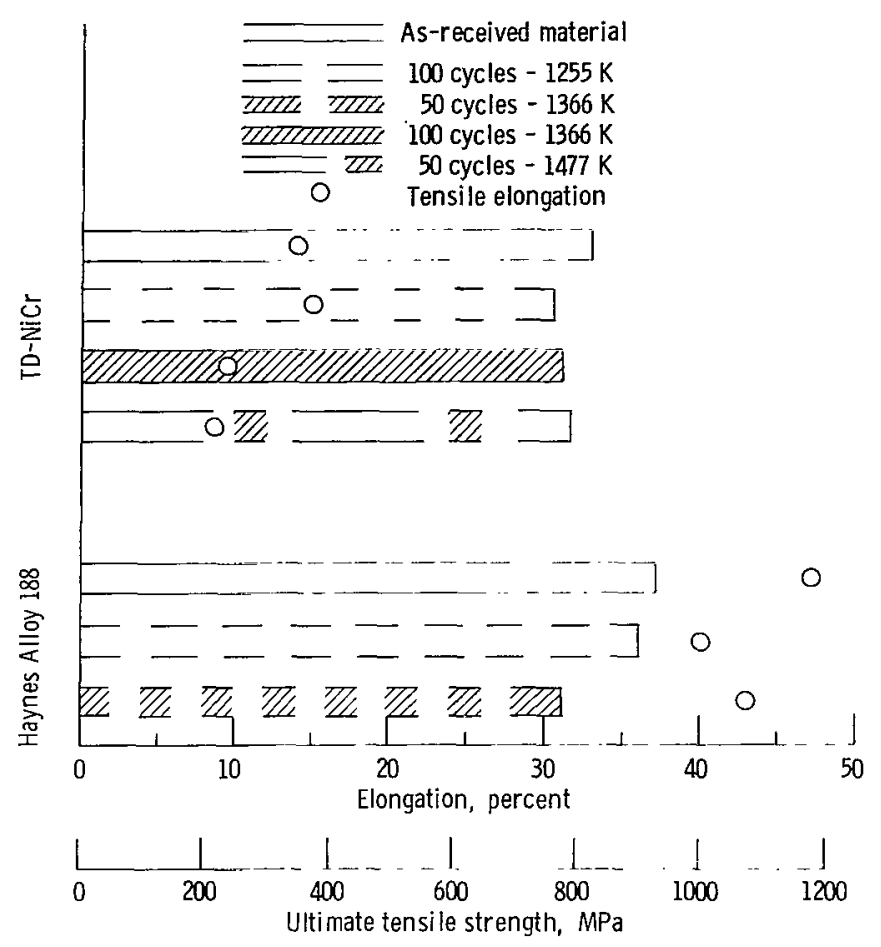

(a) Room temperature tensile properties.

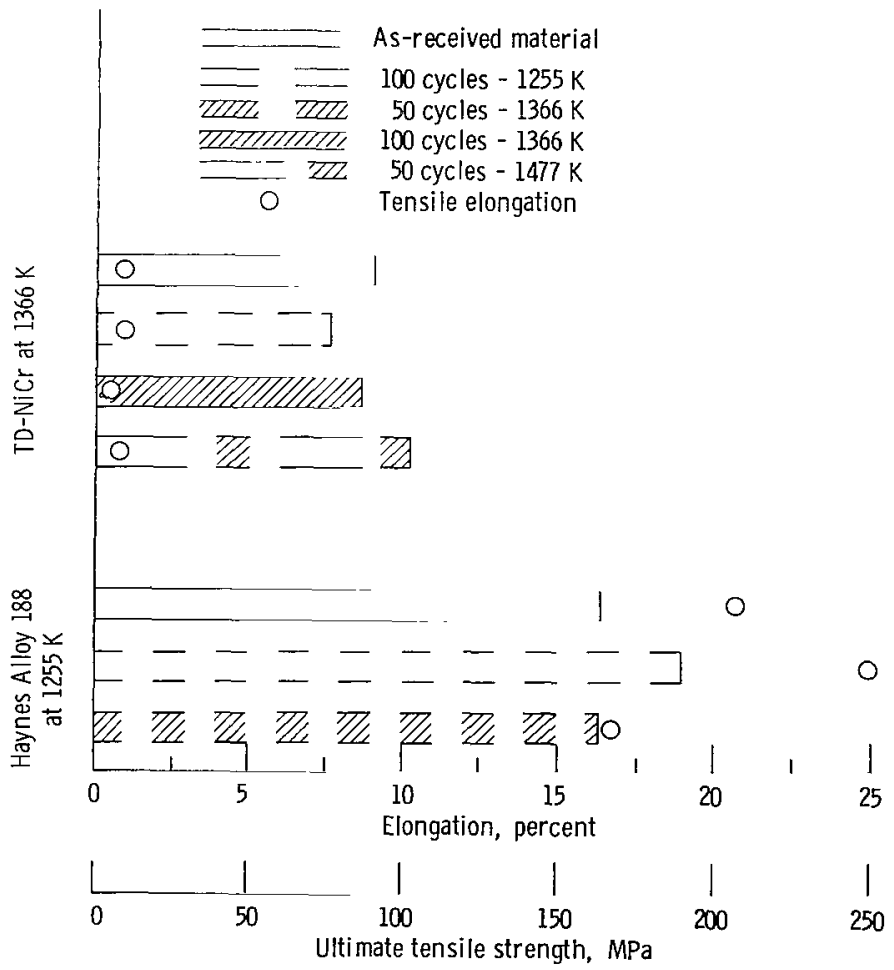

(b) Elevated temperature tensile properties.

Figure 5. - Average mechanical properties of as-received and Plasma Arc Tunnel exposed TD-NiCr and Haynes Alloy 188. 

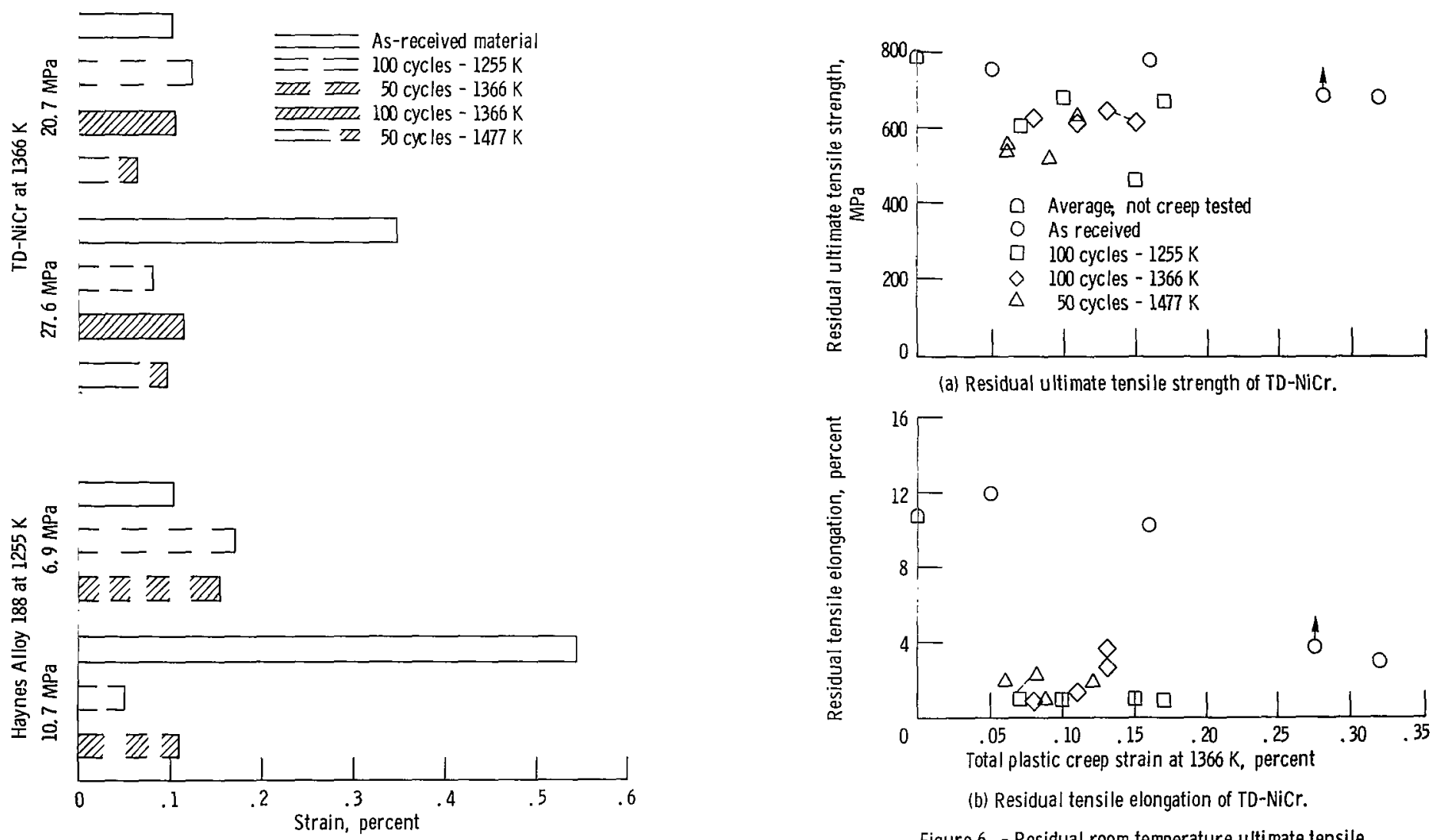

(c) Total plastic creep strain after 150 hours of creep testing at elevated temperature.

Figure 5. - Concluded. 


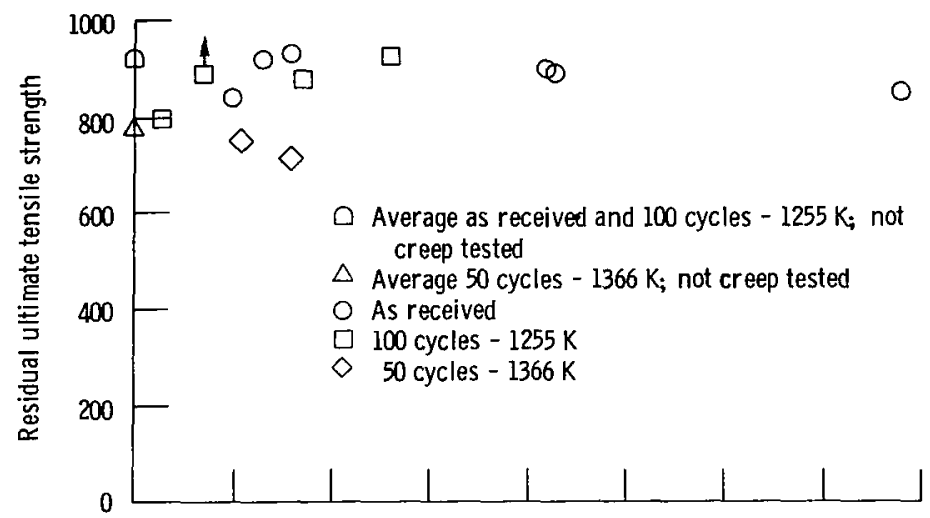

(c) Residual ultimate tensile strength of Haynes f lloy 188.

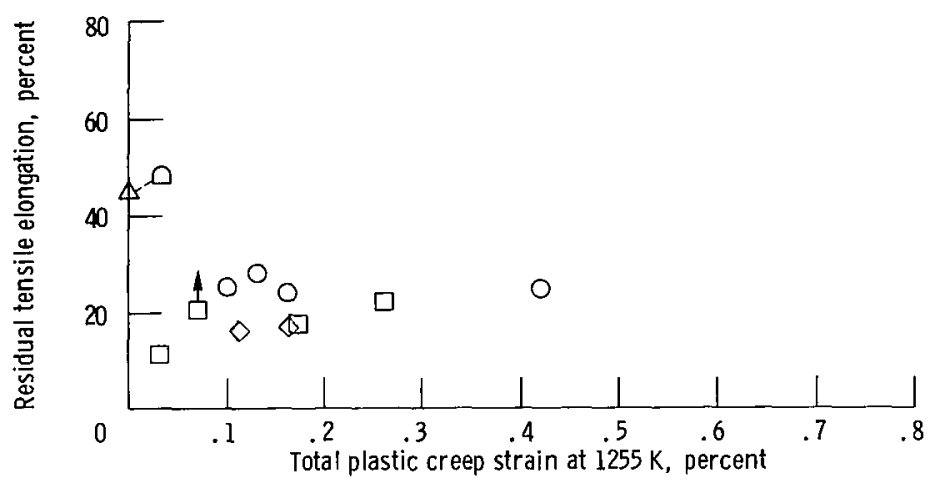

(d) Residual tensile elongation of Haynes Alloy 188.

Figure 6. - Concluded. 


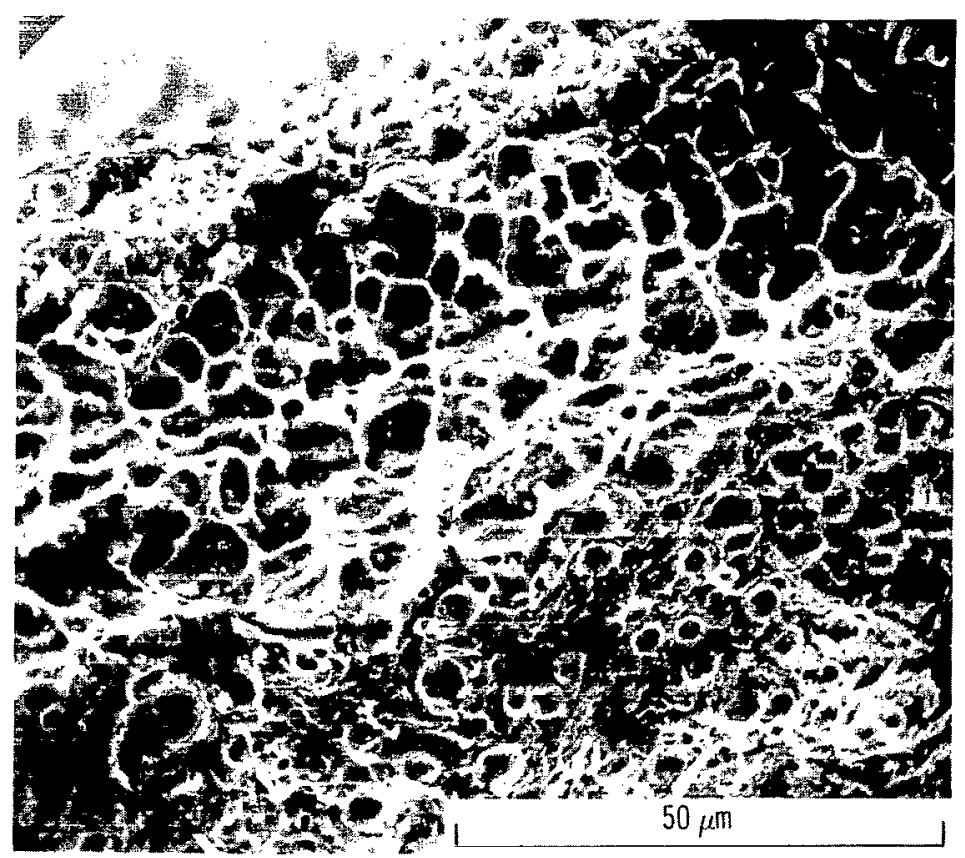

(a) Plasma arc tunnel exposed for 100 cycles at $1366 \mathrm{~K}$.

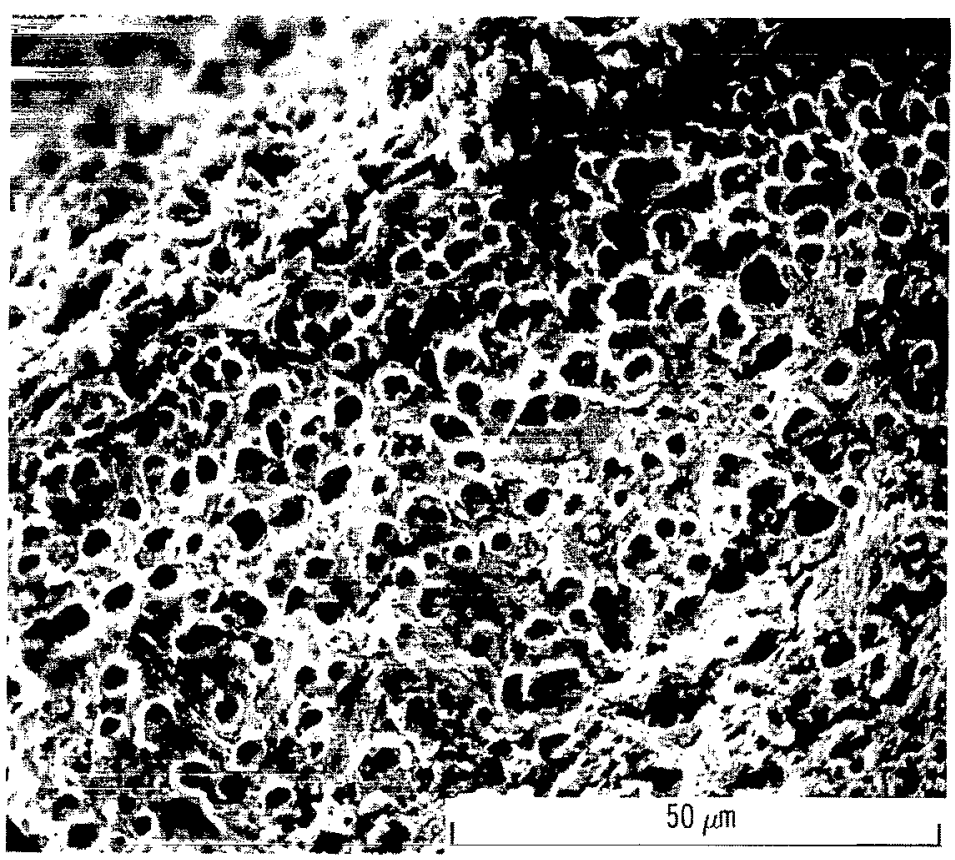

(b) Plasma arc tunnel exposed for 100 cycles at $1366 \mathrm{~K}$.

Figure 7. - Scanning electron photomicrographs of room temperature tensile fracture surfaces of as-received and PAT exposed TD-NiCr. (Figures 7 (a) and (b) are different regions on same specimen.) 


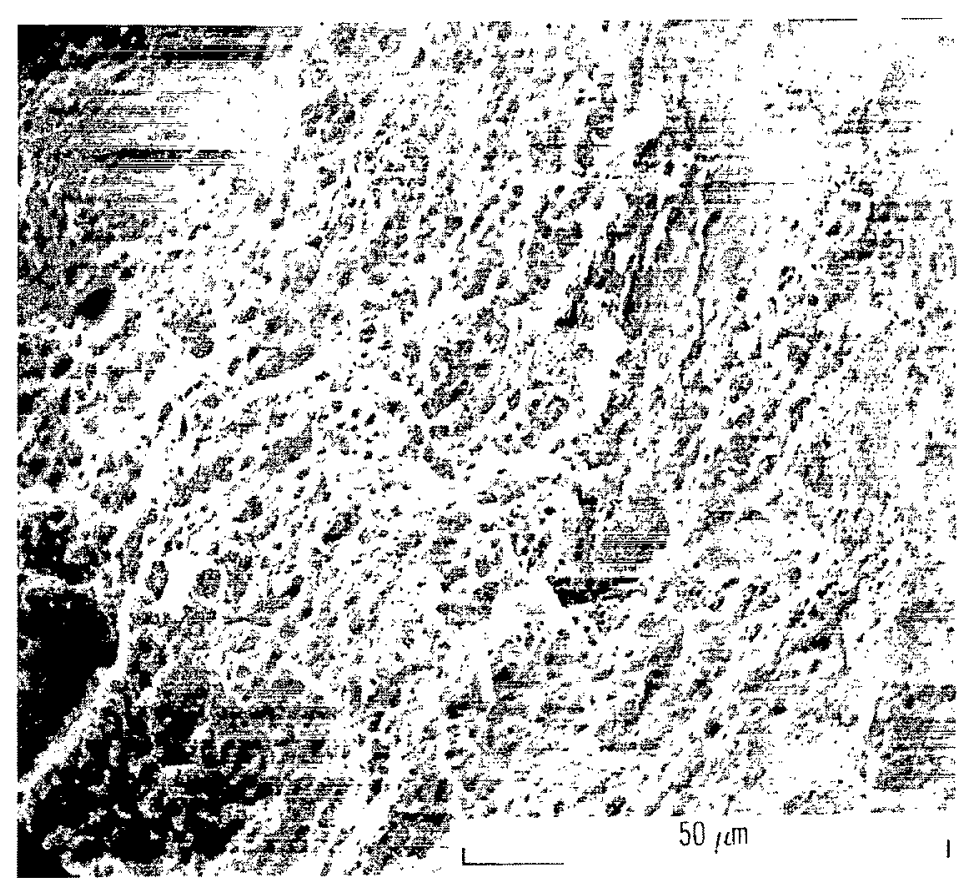

(C) As received.

Figure 7. - Concluded. 


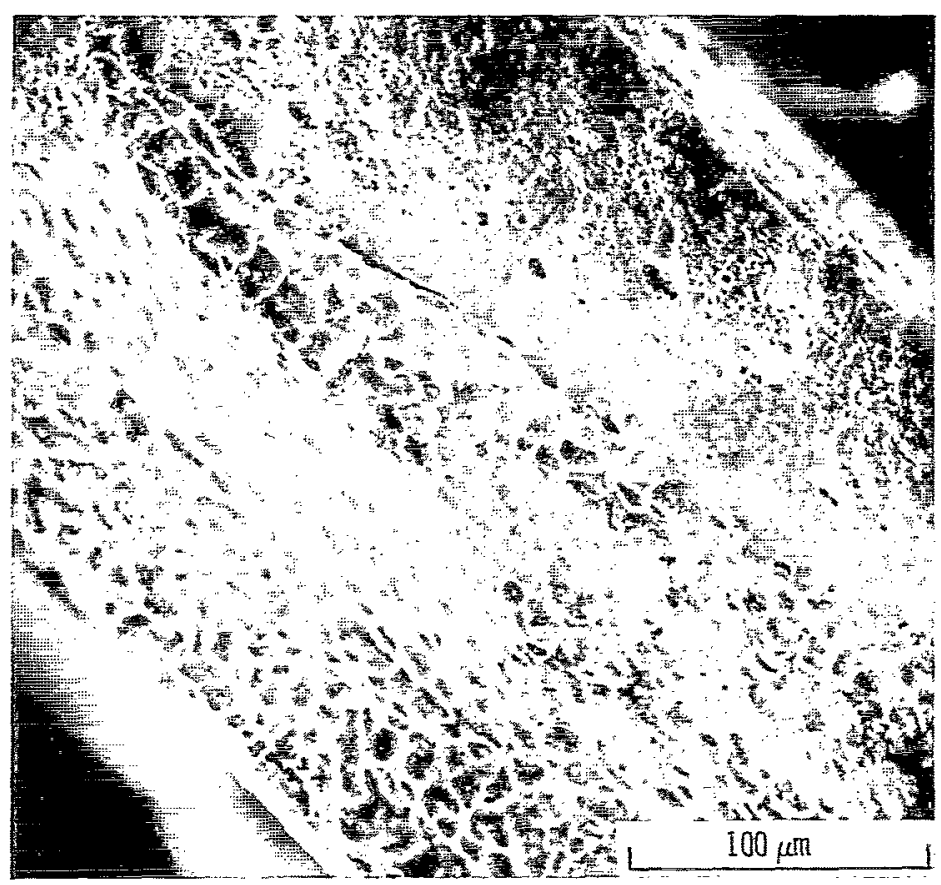

(a) As-received TD-NiCr specimen: creep tested for 150 hours at $1366 \%$, $27.6 \mathrm{MPa}, 0.32$ percent strain.

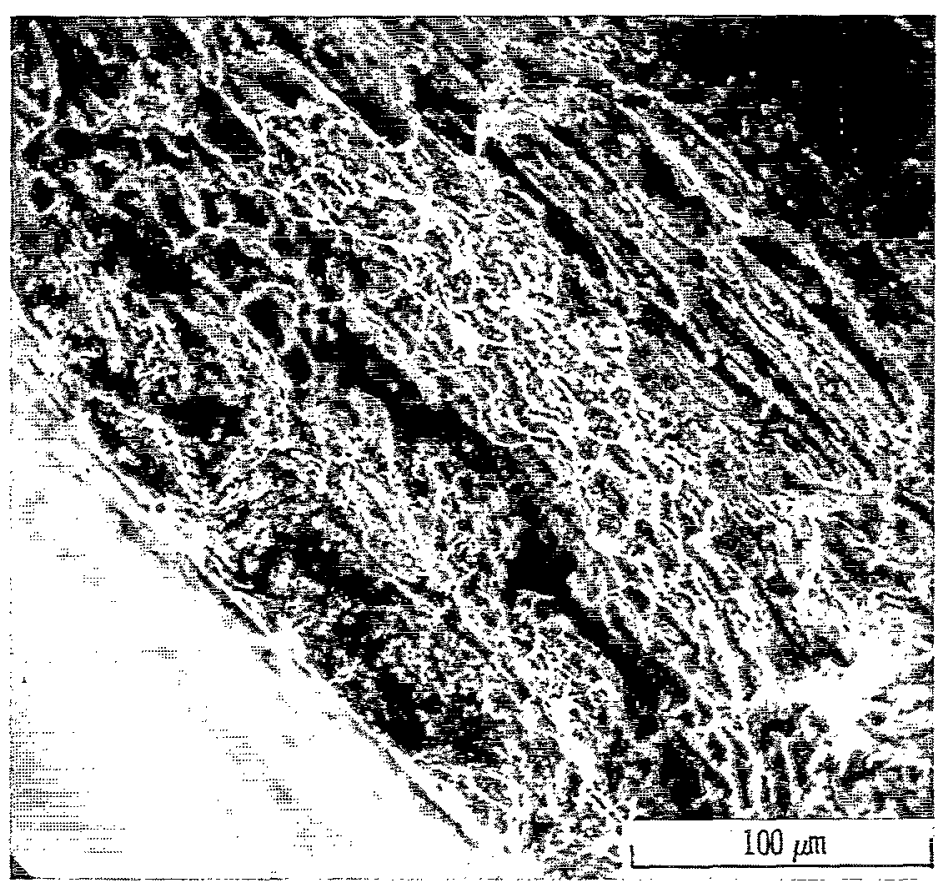

(b) DS-NiCr(I) specimen: PAT exposed for 100 cycles at $1366 \mathrm{~K}$ then creep tested for 150 hours at $1366 \mathrm{~K}, 27.6 \mathrm{MPa}, 0.35$ percent strain.

Figure 8. - Scanning electron photomicrographs of the room temperature residual tensile fracture surfaces of three ODS alloys which have suffered creep damage. 


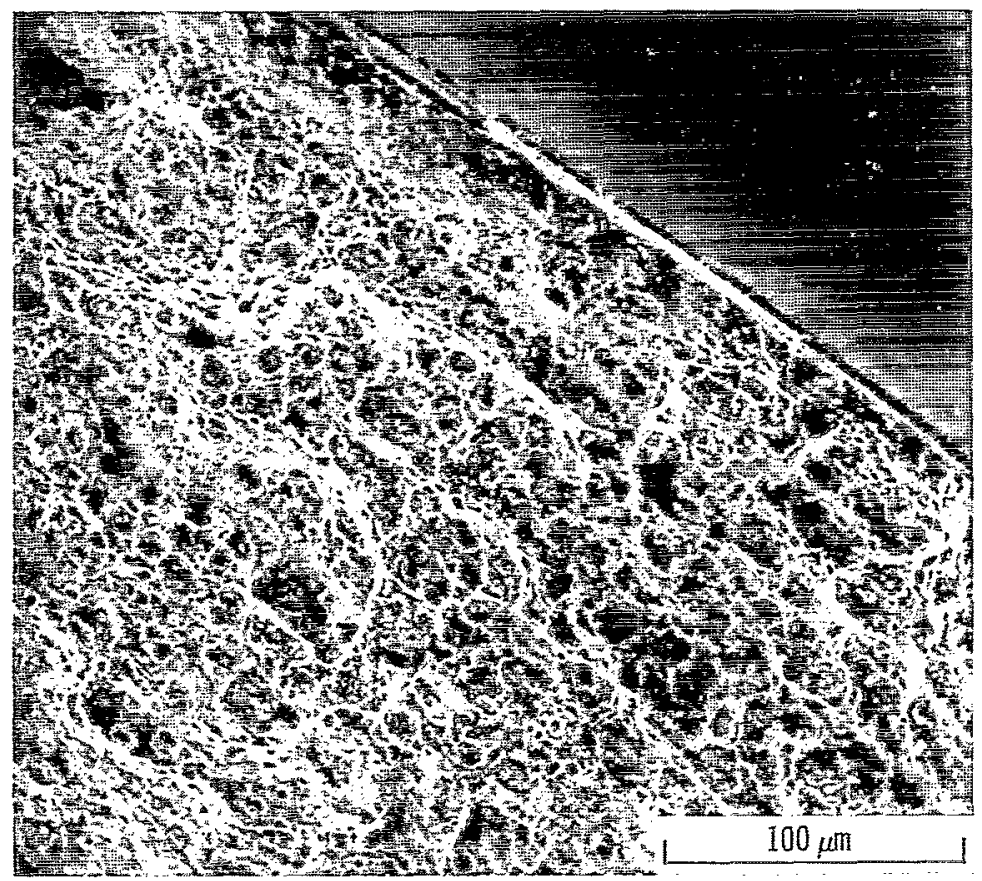

(c) As-received TD-NiCrAlY specimen: creep tested for 150 hours at $1366 \mathrm{~K}, 24.1 \mathrm{MPa}, 0.65$ percent strain.

Figure 8. - Concluded. 


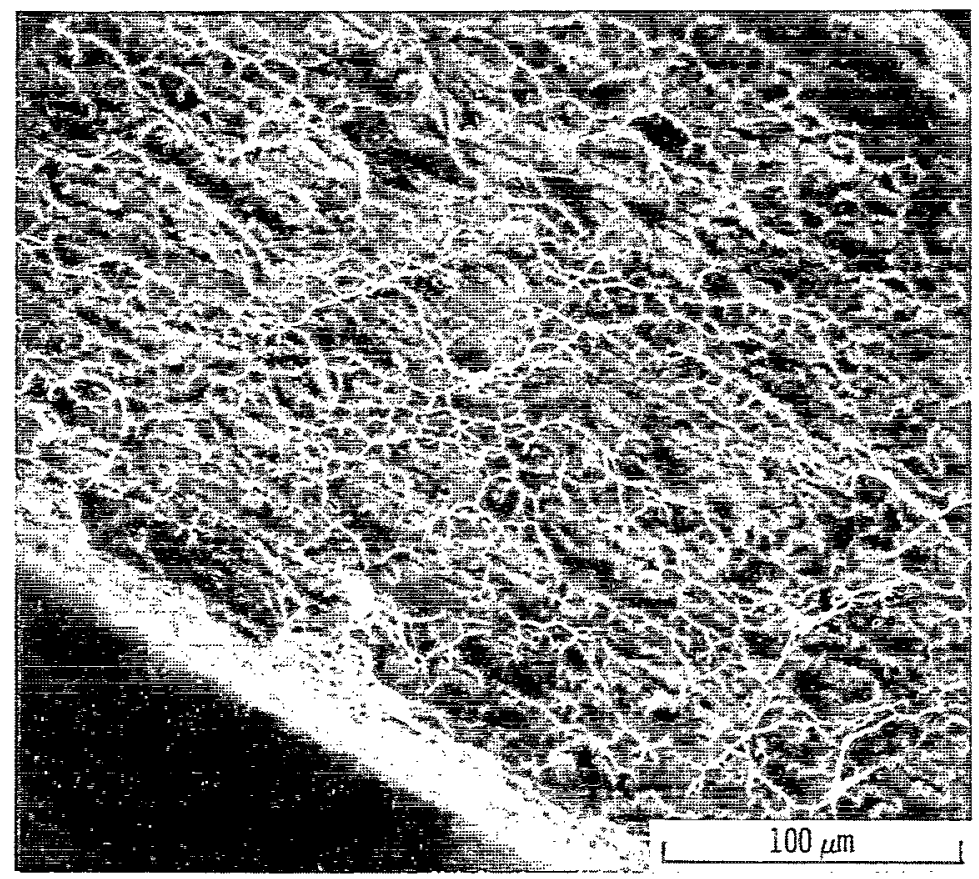

(a) As-received (not thermally exposed).

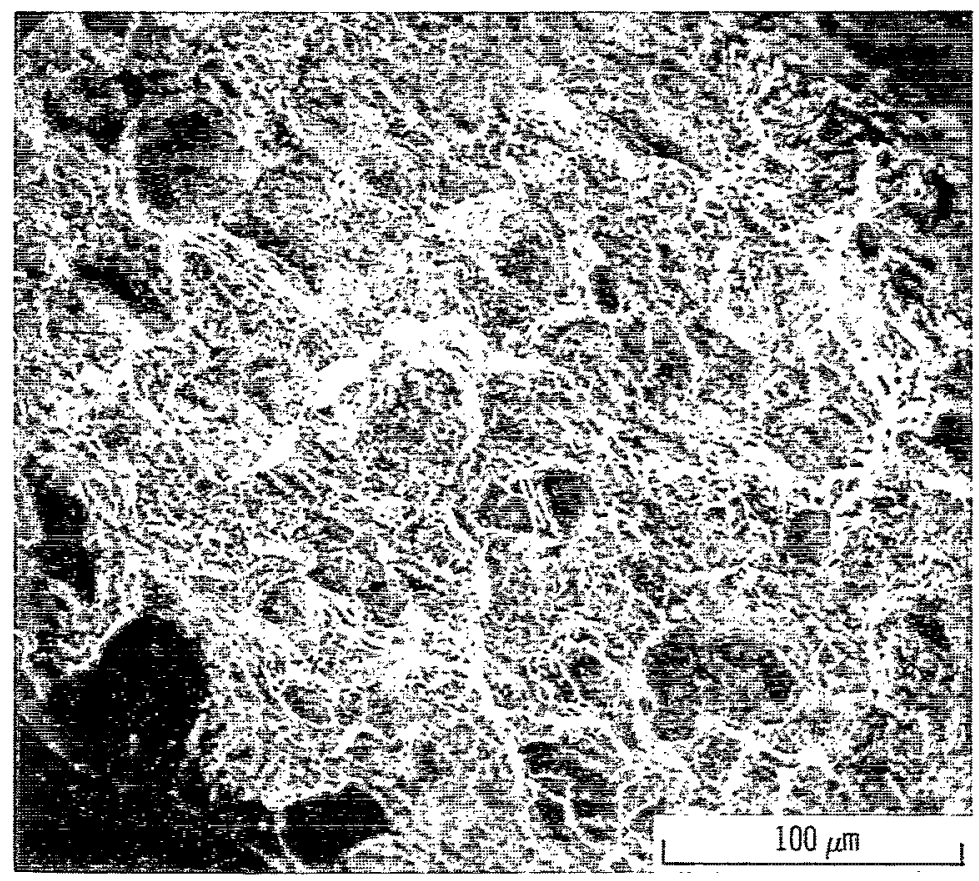

(b) PAT exposed for 100 cycles at $1255 \mathrm{~K}$; then creep tested for 150 hours at $1255 \mathrm{~K}, 6.9 \mathrm{MPa}, 0.26$ percent strain.

Figure 9. - Scanning electron photomicrographs of room temperature residual tensile fracture surfaces of Haynes Alloy 188. 

conducted so as to contribute . . . to the expansion of human knowledge of phenomena in the atmosphere and space. The Administration shall provide for the widest practicable and appropriate dissemination of information concerning its activities and the results thereof."

-National Aeronautics and Space ACt of 1958

\section{NASA SCIENTIFIC AND TECHNICAL PUBLICATIONS}

TECHNICAL REPORTS: Scientific and technical information considered important, complete, and a lasting contribution to existing knowledge.

TECHNICAL NOTES: Information less broad in scope but nevertheless of importance as a contribution to existing knowledge.

TECHNICAL MEMORANDUMS:

Information receiving limited distribution because of preliminary data, security classification, or other reasons. Also includes conference proceedings with either limited or unlimited distribution.

CONTRACTOR REPORTS: Scientific and technical information generated under a NASA contract or grant and considered an important contribution to existing knowledge.
TECHNICAL TRANSLATIONS: Information published in a foreign language considered to merit NASA distribution in English.

SPECIAL PUBLICATIONS: Information derived from or of value to NASA activities. Publications include final reports of major projects, monographs, data compilations, handbooks, sourcebooks, and special bibliographies.

\section{TECHNOLOGY UTILIZATION}

PUBLICATIONS: Information on technology used by NASA that may be of particular interest in commercial and other non-aerospace applications. Publications include Tech Briefs, Technology Utilization Reports and Technology Surveys.

Defails on the availability of these publications may be obtained from:

SCIENTIFIC AND TECHNICAL INFORMATION OFFICE 